\title{
Ecosystem Services in Biologically Diversified versus Conventional Farming Systems: Benefits, Externalities, and Trade-Offs
}

\author{
Claire Kremen $^{l}$ and $\underline{\text { Albie Miles }}^{1}$
}

\begin{abstract}
We hypothesize that biological diversification across ecological, spatial, and temporal scales maintains and regenerates the ecosystem services that provide critical inputs-such as maintenance of soil quality, nitrogen fixation, pollination, and pest control- to agriculture. Agrobiodiversity is sustained by diversified farming practices and it also supplies multiple ecosystem services to agriculture, thus reducing environmental externalities and the need for off-farm inputs. We reviewed the literature that compares biologically diversified farming systems with conventional farming systems, and we examined 12 ecosystem services: biodiversity; soil quality; nutrient management; water-holding capacity; control of weeds, diseases, and pests; pollination services; carbon sequestration; energy efficiency and reduction of warming potential; resistance and resilience to climate change; and crop productivity. We found that compared with conventional farming systems, diversified farming systems support substantially greater biodiversity, soil quality, carbon sequestration, and water-holding capacity in surface soils, energy-use efficiency, and resistance and resilience to climate change. Relative to conventional monocultures, diversified farming systems also enhance control of weeds, diseases, and arthropod pests and they increase pollination services; however, available evidence suggests that these practices may often be insufficient to control pests and diseases or provide sufficient pollination. Significantly less public funding has been applied to agroecological research and the improvement of diversified farming systems than to conventional systems. Despite this lack of support, diversified farming systems have only somewhat reduced mean crop productivity relative to conventional farming systems, but they produce far fewer environmental and social harms. We recommend that more research and crop breeding be conducted to improve diversified farming systems and reduce yield gaps when they occur. Because single diversified farming system practices, such as crop rotation, influence multiple ecosystem services, such research should be holistic and integrated across many components of the farming system. Detailed agroecological research especially is needed to develop crop- and region-specific approaches to control of weeds, diseases, and pests.
\end{abstract}

Key Words: agricultural food production; agricultural intensification; agrobiodiversity; agroecology; biodiversity; conventional agriculture; conventional farming systems; diversified farming systems; ecosystem services; land-sharing; landsparing; organic agriculture; sustainable agriculture; sustainable intensification

\section{INTRODUCTION}

While modern, industrialized agricultural systems in theory produce sufficient food to feed the world's current population, they have accomplished this feat with significant ecological and social externalities (Hazell and Wood 2008). Food needs are projected to double by 2050. It is a global imperative to meet this growing demand for food in a manner that is socially equitable and ecologically sustainable over the long term. Here we examine the ecological benefits of using biologically diversified farming systems, as well as their potential to mitigate environmental externalities of conventional farming systems and their ability to contribute to global food security as world population rises to 9 billion.

We define a diversified farming system as a system of agricultural production that, through a range of practices, incorporates agrobiodiversity across multiple spatial and/or temporal scales (Altieri 2004, Pearson 2007, Jackson et al. 2009, Tomich et al. 2011, Kremen et al. 2012).

Diversified farming systems share much in common with organic, multifunctional, sustainable, and agroecological management approaches and outcomes. The key indicators of a diversified farming system is that diversification across ecological, spatial, and temporal scales serves as the mechanism for maintaining and regenerating the biotic interactions and, in turn, the ecosystem services-e.g., soil quality, nitrogen fixation, pollination, and pest control- that provide critical inputs to agriculture (see also Shennan 2008). Across ecological scales, a diversified farming system includes several or all of: (1) genetic diversity within crop or livestock varieties; (2) varietal diversity within a single crop or livestock species; (3) multiple intercropped species, and/or integration of fish or livestock species; and (4) noncrop plantings and seminatural communities of plants and animals, such as insectary strips, hedgerows, riparian buffers, pastures, and woodlots. Across spatial scales, diversified farming systems promote agrobiodiversity through practices located within field (e.g., composting, intercropping, insectary strips, agroforestry), across the whole field (e.g., crop rotations, cover cropping, fallowing), around field perimeters (e.g., hedgerows, border plantings, grass strips), across multiple fields (mosaics of crop types and land-use practices), and at 
Table 1. Relationship between diversified farming system practices and the provisioning of ecosystem services.

\begin{tabular}{|c|c|c|c|c|c|c|c|c|c|c|c|}
\hline $\begin{array}{l}\text { Ecosystem } \\
\text { service }\end{array}$ & $\begin{array}{l}\text { Compost } \\
\text { or manure }\end{array}$ & Intercrop & Agroforestry & $\begin{array}{l}\text { Insectary } \\
\text { strip }\end{array}$ & $\begin{array}{l}\text { No till or } \\
\text { low till }\end{array}$ & Rotation & $\begin{array}{l}\text { Cover crop } \\
\text { or green } \\
\text { manure }\end{array}$ & Fallow & $\begin{array}{l}\text { Border } \\
\text { planting }\end{array}$ & $\begin{array}{c}\text { Riparian } \\
\text { buffers }\end{array}$ & $\begin{array}{c}\text { Woodlots, } \\
\text { meadows, } \\
\text { forests }\end{array}$ \\
\hline $\begin{array}{l}\text { Biodiversity } \\
\text { (above and } \\
\text { below } \\
\text { ground) }\end{array}$ & $\mathrm{x}$ & $\mathrm{x}$ & $\mathrm{x}$ & $\mathrm{x}$ & $\mathrm{x}$ & $\mathrm{x}$ & $\mathrm{x}$ & $\mathrm{x}$ & $\mathrm{x}$ & $\mathrm{x}$ & $\mathrm{x}$ \\
\hline Soil & $\mathrm{x}$ & $\mathrm{x}$ & $\mathrm{x}$ & & $\mathrm{x}$ & $\mathrm{x}$ & $\mathrm{x}$ & $\mathrm{x}$ & & $\mathrm{x}$ & $\mathrm{x}$ \\
\hline $\begin{array}{l}\text { Nutrient } \\
\text { management }\end{array}$ & $\mathrm{x}$ & & & & & $\mathrm{x}$ & $\mathrm{x}$ & & $\mathrm{x}$ & $\mathrm{x}$ & $\mathrm{x}$ \\
\hline $\begin{array}{l}\text { Water- } \\
\text { holding } \\
\text { capacity }\end{array}$ & $\mathrm{x}$ & & $\mathrm{x}$ & & $\mathrm{x}$ & & $\mathrm{x}$ & $\mathrm{x}$ & & & \\
\hline $\begin{array}{l}\text { Weed } \\
\text { control }\end{array}$ & & $\mathrm{x}$ & $\mathrm{x}$ & & & $\mathrm{x}$ & $\mathrm{x}$ & & & & \\
\hline $\begin{array}{l}\text { Disease } \\
\text { control }\end{array}$ & $\mathrm{x}$ & $\mathrm{x}$ & $\mathrm{x}$ & & & $\mathrm{x}$ & $\mathrm{x}$ & & & & \\
\hline $\begin{array}{l}\text { Pest } \\
\text { control }\end{array}$ & & $\mathrm{x}$ & $\mathrm{x}$ & $\mathrm{x}$ & & $\mathrm{x}$ & $\mathrm{x}$ & $\mathrm{x}$ & $\mathrm{x}$ & $\mathrm{x}$ & $\mathrm{x}$ \\
\hline Pollination & & $\mathrm{x}$ & $\mathrm{x}$ & $\mathrm{x}$ & & $\mathrm{x}$ & $\mathrm{x}$ & $\mathrm{x}$ & $\mathrm{x}$ & $\mathrm{x}$ & $\mathrm{x}$ \\
\hline $\begin{array}{l}\text { Carbon } \\
\text { sequestration }\end{array}$ & $\mathrm{x}$ & & $\mathrm{x}$ & & $\mathrm{x}$ & & $\mathrm{x}$ & $\mathrm{x}$ & $\mathrm{x}$ & $\mathrm{x}$ & $\mathrm{x}$ \\
\hline $\begin{array}{l}\text { Energy-use } \\
\text { efficiency }\end{array}$ & $\mathrm{x}$ & $\mathrm{x}$ & $\mathrm{x}$ & $\mathrm{x}$ & & $\mathrm{x}$ & $\mathrm{x}$ & & $\mathrm{x}$ & & \\
\hline $\begin{array}{l}\text { Resilience } \\
\text { to drought }\end{array}$ & $\mathrm{x}$ & & $\mathrm{x}$ & & $\mathrm{x}$ & & $\mathrm{x}$ & $\mathrm{x}$ & & $\mathrm{x}$ & \\
\hline $\begin{array}{l}\text { Resilience } \\
\text { to } \\
\text { hurricanes/ } \\
\text { heavy rains }\end{array}$ & $\mathrm{x}$ & $\mathrm{x}$ & $\mathrm{x}$ & & $\mathrm{x}$ & $\mathrm{x}$ & $\mathrm{x}$ & $\mathrm{x}$ & $\mathrm{x}$ & $\mathrm{x}$ & $\mathrm{x}$ \\
\hline $\begin{array}{l}\text { Productivity/ } \\
\text { yield }\end{array}$ & $\mathrm{x}$ & $\mathrm{x}$ & $\mathrm{x}$ & $\mathrm{x}$ & $\mathrm{x}$ & $\mathrm{x}$ & $\mathrm{x}$ & $\mathrm{x}$ & & & \\
\hline Scale & \multicolumn{4}{|c|}{ Within-field } & \multicolumn{4}{|c|}{ Field } & Perimeter & \multicolumn{2}{|c|}{ Landscape } \\
\hline
\end{tabular}

the landscape-to-regional scale (e.g., riparian buffers, woodlots, pastures, and natural or seminatural areas). Across temporal scales, asynchronous tilling, planting, harvesting, cover cropping, crop rotations, fallowing, or flooding contribute to the maintenance of landscape-scale heterogeneity (Shennan 2008), while no-till, perennial grass, forb or tree cropping systems, hedgerow set-asides, and forest gardens allow the natural processes of ecological succession to enhance agrobiodiversity dynamically (Altieri 2004, Glover et al. 2007, Bhagwat et al. 2008).

Agrobiodiversity is sustained by diversified farming system practices and it also supplies multiple ecosystem services to agriculture, thereby reducing the need for off-farm inputs. For example, through composting and manuring, soils are produced that harbor diverse microbial and invertebrate communities which in turn promote nutrient cycling (Mäder et al. 2002, Reganold et al. 2010). Through intercropping of nitrogen-fixing legumes with grains, farmers achieve the wellknown phenomenon of "over-yielding"-i.e., the production of a larger amount of each crop per unit area relative to production in monoculture-thereby increasing yields while reducing or eliminating fertilizer inputs (Vandermeer 1992).
Intercropping is thought to promote over-yielding because different crops grown together can utilize more of the available resources (e.g., crops with different rooting depths can access a larger fraction of spatially stratified nutrients and water) or because one crop facilitates the growth of the other (HauggardNeilsen and Jensen 2005). By enhancing floral diversity on farms through insectary strips, hedgerows, or retention of seminatural areas, farmers may enhance or attract natural enemies and/or wild pollinators to their crops and thereby increase pest control or reduce or eliminate the need for honey bee rentals (Kremen et al. 2002, Morandin and Winston 2005, Letourneau et al. 2011). The supply of these ecosystem services (e.g., soil fertility, pest control, pollination) is critically dependent on the maintenance of the underlying biodiversity - from soil microbes to flora and fauna-and on their interactions (Altieri and Nicolls 2004, Hooper et al. 2005, Zhang et al. 2007, Hajjar et al. 2008, Shennan 2008, Jackson et al. 2009). Maintaining diversity across scales through diversified farming system practices not only enhances these ecosystem services (Table 1) but promotes their resilience in the face of disturbances such as drought, deluge, or pest infestations (Tengo and Belfrage 2004, Lin 2011). 
Increasingly in the Global South and largely in the north, diversified farming systems have been replaced with highly simplified industrial monocultures (Benton et al. 2003, Tscharntke et al. 2005, DeFries et al. 2010). Average field and farm sizes have increased, while noncrop areas in and around farms have decreased, leading to higher levels of homogeneity at both the field and landscape scales. The collective simplification of agroecosystems has led to a loss of biodiversity and to reductions in the supply of key ecosystem services to and from agriculture (Tscharntke et al. 2005, Zhang et al. 2007). Without these ecosystem services, monocultures become dependent on off-farm inputs. For example, without the integration of farming practices that fix nitrogen, make efficient use of nutrients, and build soil fertility (see Table 1), growers must purchase and apply synthetic fertilizers. Similarly, without practices that prevent the build-up of pests and pathogens and promote diverse communities of natural enemies, growers must purchase and apply pesticides. While effective in producing high yields, conventional chemical inputs that substitute for ecosystem services contribute to significant environmental and social harms, including soil degradation, eutrophication of surface and groundwater, loss of biodiversity, increased greenhouse gas emissions, marine dead zones, and occupational and dietary exposure to toxic agrochemicals (Tilman et al. 2002, Diaz and Rosenberg 2008, Hayes et al. 2010, Marks et al. 2010, Gomiero et al. 2011a). Industrialized agriculture is also partially responsible for creating a range of social and economic impacts, including loss of access to land, corporate control of agricultural inputs, and the inability of small-scale producers to compete on the global market, resulting in high rates of poverty and the loss of food security for small holders (Bacon et al. 2012, Iles and Marsh 2012).

We assessed the ecological performance of biologically diversified farming systems as compared with conventional (industrialized) systems across 12 key ecosystem services that represent inputs to farming (e.g., soil fertility), mitigation of externalities associated with farming (e.g., energy-use efficiency), adaptation of farming to environmental change (e. g., resistance and resilience to extreme weather events), and outputs from farming (crop productivity) (Table 2). We begin by discussing biodiversity, because it underlies all other services (Millennium Ecosystem Assessment 2005), and then we discuss the related services of soil quality maintenance, nutrient management, and water-holding capacity. Next we cover control of weeds, plant pathogens, and arthropod pests. We continue with pollination services, and then with climaterelated services, including carbon sequestration, energy-use efficiency/reduction of global-warming potential, and the resistance and resilience of farming systems to extreme weather events. Finally, we consider crop productivity, including discussion of the potential trade-off of lowered yields against biodiversity and habitat conservation.

\section{METHODS}

For each service, we identified representative scientific literature in a Web of Science search using the terms specified in Table 2. We looked for papers that compared biologically based, diversified farming systems (including organic) with chemically based, biologically simplified conventional farming systems (i.e., those reliant on monoculture, inorganic fertilizers, and synthetic chemical pest-control inputs). We reviewed these papers and prioritized the following types of studies (in descending order) for inclusion in our review: (1) meta-analyses or quantitative syntheses; (2) studies of longterm systems $(7+$ years $)$ or highly replicated, multiregion studies; and (3) review articles including "vote counts". We prioritized meta-analyses and quantitative syntheses because such studies use statistical methods for combining research results and extracting overall trends from multiple studies that on their own may present conflicting results (Rosenthal and Matteo 2001). Next, we included long-term or highly replicated multiregion studies, because such studies draw inferences that incorporate temporal or spatial variance, and are thus more likely to represent robust conclusions. Finally, when no meta-analyses or quantitative syntheses were available, we utilized reviews with "vote-counts" — while such reviews do not have the ability to resolve conflicts among study results, they provide a qualitative summary of multiple studies, and an assessment of the number of studies in that topic area. In some cases, we identified additional papers from the reference lists of the included papers.

While not all organic agriculture meets the definition of a diversified farming system (Kremen et al. 2012), organic systems frequently use many of the techniques utilized in diversified farming systems (especially compost, cover crops, crop rotation, and absence of synthetic pesticides and fertilizers). There is a relatively large body of literature comparing organic with conventional agriculture, whereas this is not always the case for diversified farming systems. We therefore frequently used organic as a proxy for diversified farming systems, but recognize the limitations this may impose. We also included comparisons across gradients of land-use intensification, when appropriate.

\section{RESULTS AND DISCUSSION}

\section{Biodiversity}

Multiple meta-analyses have shown that organic farming increases species abundance and richness locally, but its effects differ between taxonomic groups, and with landscape context and intensiveness of production systems (Table 3, Bengtsson et al. 2005, Fuller et al. 2005, Attwood et al. 2008, Gabriel et al. 2010, Batáry et al. 2011). In a meta-analysis of 66 publications, Bengtsson et al. (2005) found that organisms were 50\% more abundant and species richness was 30\% greater in organic farming systems than in conventional farming systems. Specifically, abundance and, in most cases, 
Table 2. Search terms utilized for each ecosystem service. Services are categorized as to whether they provide an input to farming, an output from farming, mitigation of an environmental externality, or adaptation to global change.

\begin{tabular}{|c|c|c|}
\hline $\begin{array}{l}\text { Performance indicator or } \\
\text { ecosystem service }\end{array}$ & $\begin{array}{l}\text { Category of ecosystem } \\
\text { service }\end{array}$ & Web of Science: topic-specific search terms \\
\hline Biodiversity & Input and output ${ }^{\dagger}$ & ("biodiversity" OR "biological diversity" OR “species richness" OR “species abundance”) \\
\hline Soil quality & Input, mitigation & $\begin{array}{l}\text { ("soil structure" OR "soil erosion" OR "soil organic matter" OR “organic matter content" } \\
\text { OR “carbon sequestration" OR "soil carbon" OR "soil quality" OR "soil biological } \\
\text { diversity" OR "soil biological activity" OR "water-holding capacity" OR "porosity" OR } \\
\text { "permeability" OR "percolation" OR "aggregation" OR "aggregate stability" OR "soil } \\
\text { erosion") }\end{array}$ \\
\hline Nutrient management & Input, mitigation & $\begin{array}{l}\text { ("nutrient management" OR “nitrogen management" OR "phosphorus management" OR } \\
\text { "nutrient leaching" OR "nitrogen leaching" OR "nitrate leaching" OR "phosphorus } \\
\text { leaching") }\end{array}$ \\
\hline Water-holding capacity & Input & $\begin{array}{l}\text { ("water-use efficiency" OR “water-holding capacity" OR "porosity” OR "permeability” OR } \\
\text { "percolation") }\end{array}$ \\
\hline Control of weeds & Input & $\begin{array}{l}\text { ("pest control" OR “weed control” OR "weed suppression" OR "weed management" OR } \\
\text { "weed pressure" OR "weed density") }\end{array}$ \\
\hline Control of plant pathogens & Input & $\begin{array}{l}\text { ("pathogens" OR "plant pathogens" OR "pest control" OR "pathogen control" OR "pathogen } \\
\text { suppression" OR "pathogen management" OR "disease management" OR "soil borne } \\
\text { pathogens") }\end{array}$ \\
\hline Control of arthropod pests & Input & $\begin{array}{l}\text { ("pest control" OR "pest management" OR "arthropod pest management" OR "pest } \\
\text { regulation" OR "biocontrol" OR "biological control" OR "conservation biological control" } \\
\text { OR "natural enemies" OR "beneficial arthropods" }\end{array}$ \\
\hline Pollination services & Input & (“pollination” OR “pollination services” OR “crop pollination") \\
\hline Carbon sequestration & Mitigation & $\begin{array}{l}\text { ("carbon sequestration" OR "soil carbon" OR "carbon capture" OR "green house gas } \\
\text { emissions") }\end{array}$ \\
\hline $\begin{array}{l}\text { Energy-use efficiency and } \\
\text { global warming potential }\end{array}$ & Mitigation & $\begin{array}{l}\text { ("energy use" OR "energy consumption" OR "energy-use efficiency" OR "energy" OR } \\
\text { "green house gasses" OR "global warming potential") }\end{array}$ \\
\hline $\begin{array}{l}\text { Resiliency to environmental } \\
\text { disturbances: drought }\end{array}$ & Adaptation & $\begin{array}{l}\text { ("resiliency" OR "stability" OR "adaptation" OR “environmental disturbances" OR } \\
\text { "extreme weather" OR "drought") }\end{array}$ \\
\hline $\begin{array}{l}\text { Resiliency to environmental } \\
\text { disturbances: hurricane and } \\
\text { heavy rainfall }\end{array}$ & Adaptation & $\begin{array}{l}\text { ("resiliency" OR "stability” OR “adaptation" OR “environmental disturbances" OR } \\
\text { "extreme weather" OR "hurricane") }\end{array}$ \\
\hline Crop productivity/yield & Output & (“productivity" OR "yield") \\
\hline
\end{tabular}

Web of Science: common search terms

AND ("ecoagriculture" OR "sustainable agriculture" OR "agroecology" OR "organic farming" OR "organic agriculture" OR "poly-culture" OR "diversified farming system" OR "traditional farming systems" OR "intercropping" OR "crop diversity" OR "multicropping" OR "agrobiodiversity" OR "hedgerow" OR "insectary strip" OR "cover cropping" OR "crop rotation" OR "no-till agriculture" OR "agroforestry" OR "alley cropping" OR "livestock integration" OR “compost" OR "green manure")

\footnotetext{
${ }^{\dagger}$ Biodiversity plays a fundamental role as an input to all other ecosystem services, and is also a desirable cultural service that can be produced by agroecosystems (Millennium Ecosystem Assessment 2005).

richness of birds, predatory insects, soil organisms, and plants responded positively to organic farming, while nonpredatory insects and pests responded negatively. The largest positive effects of organic farming on biodiversity were found in more intensively managed agricultural landscapes. Also using meta-

analysis, Attwood et al. (2008) found arthropod predators and decomposers to be significantly more species rich under reduced-input cropping than conventional cropping, although arthropod herbivores (i.e., pests) were not. Similarly, in a meta-analysis of European agri-environment management
} 
(AEM) schemes (46 studies with 109 comparisons, 75\% of which were organic versus conventional, but also including field-margin enhancements and reduced tillage, mowing, or grazing), Batáry et al. (2011) found that agri-environment management in croplands and grasslands significantly increased species richness and abundance of plants, pollinators, arthropods, and birds. For many of the taxonomic groups and response variables, agri-environment management had significant positive effects only in simple landscapes that contained $<20 \%$ of seminatural habitats.

Three recent multiregion studies from Europe have also demonstrated the negative effects of both agricultural intensification (increased use of synthetic fertilizers and pesticides combined with reduced use of diversified farming system techniques) and landscape simplification on components of biodiversity. On 153 cereal fields in five regions of Europe, Winqvist et al. (2011) found significant declines of plant and bird richness and abundance — but not of ground beetle-for conventionally managed farms relative to organically managed farms, and for farm sites in simplified landscapes (i.e., containing a larger proportion of arable land). In a related study on 270 cereal fields in nine regions of Europe, Geiger et al. (2010) found significant declines of plant, bird, and carabid beetle richness with decreasing proportions of the landscape under agri-environment management schemes, and with various metrics of local-scale management intensification. In a study of 192 fields over four regions in the United Kingdom, Gabriel et al. (2010) found support for significant positive effects of organic management at both local and landscape scales on a wide range of organisms.

In the tropics, small-scale agroforests and home gardens are intensively managed, family farming systems where multipurpose native and non-native trees and shrubs are frequently integrated with annual and perennial crops and small livestock. While such agroforestry systems are typically less species rich than native forests (Scales and Marsden 2008, Jackson et al. 2009), agroforestry systems support significant components of tropical biodiversity (e.g., 25 to $65 \%$ of forestdwelling plants and animals across 9 taxa and 14 countries (Bhagwhat et al. 2008: 36 studies, 69 comparisons)), as do landscape mosaics comprising farmlands and natural or seminatural habitats (Daily et al. 2001, Mayfield and Daily 2005). Management intensification in tropical agroforestry systems causes declines in species richness. Scales and Marsden (2008) reviewed studies of slash-and-burn fields, home gardens, and complex agroforestry systems (not including coffee), concluding that increased disturbance and reduced rates of forest regeneration decreased species richness in $83 \%$ of studies $(N=24)$. For coffee systems in Latin America, Philpott et al. (2008a), using meta-analysis, found that management intensification caused declines in bird $(N=$ $12)$ but not ant $(N=4)$ species. Furthermore, for ants and birds, rustic coffee agroforestry systems (native forest canopy with low-density coffee understory) had similar or higher species richness relative to intact forests, but all other management forms (traditional polyculture, shade or sun monoculture) lost species relative to intact forests. Like studies from temperate regions, both local-scale management intensification and the proportion of forest cover in the landscape, and their interaction, all influence species richness in agroecosystems, as Anand et al. (2010) found using model selection in a quantitative synthesis of 17 studies across a wide range of taxa (30 comparisons) comparing different land uses (monoculture plantations, diverse plantings, logged forests, and forest fragments) in the Western Ghats, India. Forest cover at the landscape scale appeared to be the dominant factor influencing species richness patterns; at the local scale, monoculture plantations had the most consistently negative effect on species richness relative to other land uses.

Collectively these results show that the biodiversity benefits of diversified farming practices are significant at the local scale but tend to be most dramatic in simplified landscapes that are dominated by monoculture cropping systems with few natural habitat remnants. In contrast, complex landscapes with high percentages of noncrop habitats may already support high levels of biodiversity, both locally and regionally (Daily et al. 2001, Tscharntke et al. 2005, Batáry et al. 2010); thus localscale diversification may have limited additional effects in such contexts. The cumulative effects of local-scale adoption of organic or diversified farming practices, however, can also have positive landscape-scale effects on biodiversity (e.g., Holzschuh et al. 2008, Gabriel et al. 2010, Geiger et al. 2010). In addition, the preservation of natural areas such as source habitats is critical for the maintenance of biodiversity (Batáry et al. 2011), including for ecosystem service providers like pollinators and natural enemies of arthropod pests (Kremen et al. 2002, Chaplin-Kramer et al. 2011). Biologically diversified farming systems are thus able to contribute to a high-quality matrix that enables the movement of forest organisms between remnant patches of natural vegetation (Perfecto and Vandermeer 2010). Nonetheless, agroecosystems and agronatural landscapes do not support all elements of biodiversity (Jackson et al. 2009); some species, including rare, endangered, or endemic species of greatest conservation concern, occur only in larger expanses of natural habitats (Kleijn et al. 2006, Bhagwat et al. 2008). Finally, these studies illustrate the concept that is core to diversified farming systems: cross-scale heterogeneity is critical for conserving biodiversity, which in turn underlies fundamental ecosystem services generating essential inputs to farming (Kremen et al. 2012).

\section{Soil quality}

Multiple studies of long-term field trials have demonstrated a strong positive impact of organic and diversified farming practices on the enhancement of key soil quality indicators (Bengtsson et al. 2005, Pimentel et al. 2005, Fliessbach et al. 
Table 3. Summary of findings.

\begin{tabular}{|c|c|c|c|c|c|}
\hline $\begin{array}{l}\text { Performance indicator } \\
\text { or ecosystem service }\end{array}$ & $\begin{array}{l}\text { Size of } \\
\text { effect }\end{array}$ & $\begin{array}{l}\text { Significance } \\
\text { of effect }\end{array}$ & $\begin{array}{l}\text { Strength of } \\
\text { evidence }^{\S}\end{array}$ & Selected key references & Explanatory notes \\
\hline \multicolumn{6}{|l|}{ Biodiversity } \\
\hline Abundance & Large+ & $*$ & Strong & Meta-analyses: & \multirow{4}{*}{$\begin{array}{l}\text { Local factors (e.g., organic vs. conventional) and landscape } \\
\text { factors (e.g., complexity) influenced biodiversity outcomes } \\
\text { in temperate and tropical regions. }\end{array}$} \\
\hline Richness & Medium+ & $*$ & Strong & $\begin{array}{l}\text { Bengtsson et al. } 2005 \text {, } \\
\text { Batáry et al. } 2011 . \\
\text { Quantitative synthesis: } \\
\text { Anand et al. } 2010 .\end{array}$ & \\
\hline \multicolumn{5}{|l|}{ Soil quality } & \\
\hline Soil organic matter & $\begin{array}{l}\text { Small to } \\
\text { Medium+ }\end{array}$ & $*$ & Strong & $\begin{array}{l}\text { Long-term study: } \\
\text { Drinkwater et al. } 1998 . \\
\text { Meta-analysis: } \\
\text { Marriott and Wander } 2006 .\end{array}$ & \\
\hline \multicolumn{6}{|l|}{ Soil } \\
\hline Physical properties & $\begin{array}{l}\text { Small to } \\
\text { Large+ }\end{array}$ & $*$ & Strong & $\begin{array}{l}\text { Long-term study: } \\
\text { Mäder et al. } 2002 .\end{array}$ & \\
\hline $\begin{array}{l}\text { Biological } \\
\text { properties }\end{array}$ & $\begin{array}{l}\text { Medium to } \\
\text { Large+ }\end{array}$ & $*$ & Strong & $\begin{array}{l}\text { Long-term studies: } \\
\text { Mäder et al. 2002, } \\
\text { Reganold et al. } 2010 \text {. }\end{array}$ & \\
\hline Erosion & Large+ & $*$ & Strong & $\begin{array}{l}\text { Long-term study: } \\
\text { Reganold et al. } 1987 .\end{array}$ & \\
\hline \multicolumn{6}{|l|}{ Nutrient management } \\
\hline Intercropping & - & - & - & $\begin{array}{l}\text { Studies: } \\
\text { Knudsen et al. } 2004 \text {, } \\
\text { Li et al. } 2007 .\end{array}$ & \multirow{5}{*}{$\begin{array}{l}\text { No meta-analyses or quantitative syntheses exist for } \\
\text { intercropping, but several well-developed studies show how } \\
\text { intercropping enhances nutrient-use efficiency. In their } \\
\text { meta-analysis, Gardner et al. (2009) show how } \\
\text { agroecological practices of crop rotation and organic } \\
\text { fertilizers enhance retention of N in the system, promoting N } \\
\text { uptake into crops and reducing losses to air and water. While } \\
\text { Mondelaers et al.'s (2009) comparison of organic vs. } \\
\text { conventional agriculture (meta-analysis) does not provide } \\
\text { convincing evidence of organic-resolving nutrient leakage } \\
\text { issues, the quantitative study of Zhang et al. (2010) } \\
\text { unequivocally demonstrates how riparian buffers, another } \\
\text { diversified farming system feature, can mitigate N and P } \\
\text { runoff into waterways. }\end{array}$} \\
\hline Crop rotation & $\begin{array}{l}\text { Small to } \\
\text { Medium+ }\end{array}$ & $*$ & Strong & $\begin{array}{l}\text { Meta-analysis: } \\
\text { Gardner et al. } 2009 .\end{array}$ & \\
\hline $\begin{array}{l}\text { Organic fertilizer } \\
\text { source }\end{array}$ & Medium+ & $*$ & Strong & $\begin{array}{l}\text { Meta-analysis: } \\
\text { Gardner et al. } 2009 .\end{array}$ & \\
\hline $\begin{array}{l}\text { Nitrogen leaching } \\
\text { Organic- } \\
\text { conventional }\end{array}$ & Small+ & $*$ & Weak & $\begin{array}{l}\text { Meta-analysis: } \\
\text { Mondelaers et al. } 2009 .\end{array}$ & \\
\hline Riparian buffer & Large+ & $*$ & Strong & $\begin{array}{l}\text { Quantitative synthesis: } \\
\text { Zhang et al. } 2010 .\end{array}$ & \\
\hline \multicolumn{6}{|l|}{ Phosphorus leaching } \\
\hline $\begin{array}{l}\text { Organic- } \\
\text { conventional }\end{array}$ & Small+ & n.s. & Equivocal & $\begin{array}{l}\text { Meta-analysis: } \\
\text { Mondelaers et al. } 2009 .\end{array}$ & \\
\hline Riparian buffer & Large+ & $*$ & Strong & $\begin{array}{l}\text { Quantitative synthesis: } \\
\text { Zhang et al. } 2010 .\end{array}$ & \\
\hline \multicolumn{6}{|l|}{ Water-holding capacity } \\
\hline & Medium+ & $*$ & Strong & $\begin{array}{l}\text { Long-term study: } \\
\text { Reganold et al. } 1997 .\end{array}$ & \multirow{4}{*}{$\begin{array}{l}\text { Lotter et al. (2003): under drought conditions, water } \\
\text { percolation doubled on organic vs. conventional fields. } \\
\text { Mäder et al. (2002): reported } 20 \text { to } 40 \% \text { higher water- } \\
\text { holding capacity in organic vs. conventionally managed soils } \\
\text { in a } 21 \text {-year long-term study. }\end{array}$} \\
\hline & $\begin{array}{l}\text { Small to } \\
\text { Large+ }\end{array}$ & $*$ & Strong & $\begin{array}{l}\text { Long-term study: } \\
\text { Lotter et al. } 2003 \text {. }\end{array}$ & \\
\hline & $\begin{array}{l}\text { Small to } \\
\text { Medium+ }\end{array}$ & $*$ & Weak to Strong & $\begin{array}{l}\text { Long-term study: } \\
\text { Mäder et al. } 2002 .\end{array}$ & \\
\hline Control of weeds & & & $\begin{array}{l}\text { Moderate to } \\
\text { Strong+ }\end{array}$ & $\begin{array}{l}\text { Vote count review: } \\
\text { Liebman and Dyck } 1992 .\end{array}$ & \\
\hline \multicolumn{6}{|c|}{ Control of plant pathogens } \\
\hline Aerial & Large+ & $*$ & Strong & $\begin{array}{l}\text { Study: } \\
\text { Zhu et al. } 2000 .\end{array}$ & \multirow{2}{*}{$\begin{array}{l}\text { Hiddink et al. (2010): while } 74.5 \% \text { of studies found a } \\
\text { significant effect of crop diversification in reducing } \\
\text { soilborne diseases, yields were still reduced substantially in } \\
\text { some systems due to soil pathogens. }\end{array}$} \\
\hline Soil & & & $\begin{array}{l}\text { Weak to } \\
\text { Moderate+ }\end{array}$ & $\begin{array}{l}\text { Vote count review: } \\
\text { Hiddink et al. } 2010 .\end{array}$ & \\
\hline \multicolumn{6}{|c|}{ Control of arthropod pests } \\
\hline Local scale & Small+ & $*$ & Weak & $\begin{array}{l}\text { Meta-analysis: } \\
\text { Letourneau et al. } 2011 .\end{array}$ & \multirow{2}{*}{$\begin{array}{l}\text { Here, we considered effects on yield as the most direct } \\
\text { measure of the ecosystem service of pest control. Few } \\
\text { studies on pest control are available at the landscape scale. } \\
\text { See text for information on other indicators of pest-control } \\
\text { services. }\end{array}$} \\
\hline Landscape scale & $\begin{array}{l}\text { None to } \\
\text { Large+ }\end{array}$ & n.s. to $*$ & Equivocal & $\begin{array}{l}\text { Meta-analysis: } \\
\text { Chaplin-Kramer et al. } 2011 . \\
\text { Multiregional study: } \\
\text { Meehan et al. } 2011 \text {. }\end{array}$ & \\
\hline \multicolumn{6}{|l|}{ Pollination services } \\
\hline & Small+ & $*$ & Weak & $\begin{array}{l}\text { Quantitative synthesis: } \\
\text { Garibaldi et al. } 2011 \text {. }\end{array}$ & $\begin{array}{l}\text { Here, we considered effects on yield as the most direct } \\
\text { measure of the ecosystem service of pollination. The }\end{array}$ \\
\hline
\end{tabular}




\section{Carbon sequestration}

\section{0-cm soil depth}

1-m soil depth

n.s.

Equivocal

Energy-use efficiency

Global-warming potential

Resiliency to environmental disturbances

Drought

Hurricanes and heavy rainfall

Small to Large+

Small-

Organic-

conventional

Developing countries

Organic-

conventional

n.s to $*$

Strong+

Equivocal

$$
\begin{aligned}
& \text { Vote count review: } \\
& \text { Lynch et al. } 2011 .
\end{aligned}
$$

Vote count review: Lynch et al. 2011. contribution of wild pollinators to crop yield may be masked in part by the ubiquitous presence of managed honey bees. See text for information on other indicators of pollination services.
Long-term studies: Syswerda et al. 2011 Dolan et al. 2006.

Long-term study: Syswerda et al. 2011 .

Long-term study: Lotter et al. 2003.

Study: Holt-Giménez et al. 2002.

In general, too few measurements deeper in soil profiles have been taken to determine effects of agricultural practices on soil C stocks (Dolan et al. 2006, Kravchencko and Roberts 2011). In the long-term study of Syswerda et al. (2011), significantly higher $C$ sequestration was found in the upper soil profiles for organic or no-till agriculture vs. conventional row-crops, but no significant difference considering the profile to $1 \mathrm{~m}$, possibly due to much higher variability in the lower soil profile layers in $\mathrm{C}$ sequestration. There are many other diversified farming system practices that can influence soil C storage (i.e., crop rotations, composting, manuring/green manuring, crop residue retention, etc.) but we lack information on how they affect soil C storage through the soil profile, either alone or in combination.

Most studies showed energy-efficiency gains that surpassed the authors' threshold of a $20 \%$ differential needed for policy action.

Uncertainty in measurements of $\mathrm{NO}_{2}$ from soils and manure contributed to high variability. Also, for some production systems, greenhouse gas emissions were higher per unit of product for organic production.

$\begin{array}{ll}\text { Strong } & \begin{array}{l}\text { Long-term study: } \\ \text { Lotter et al. } 2003 .\end{array} \\ & \\ \text { Strong } & \text { Study: } \\ & \text { Holt-Giménez et al. } 2002 .\end{array}$

(a)


2007). In particular, surface soils under organic management with high residue return rates or organic matter inputs generally have higher levels of soil organic matter (Franzluebbers 2004, Kong et al. 2005, Marriott and Wander 2006). Improved levels of soil organic matter generally enhance soil quality with respect to ten critical and interrelated functions within agroecosystems: biogeochemical cycling and retention of nutrients, soil aggregate formation and stability, water infiltration and water-holding capacity, decontamination of water, $\mathrm{pH}$ buffering, erosion reduction, and promotion of plant growth (Mäder et al. 2002, Weil and Magdoff 2004). Organic management can increase soil organic matter through recycling of crop residues and manure, green manuring, cover cropping, vegetated fallow periods, and the addition of compost. For example, in the ongoing Rodale trial involving the comparison of two organic systems with complex rotations that include legume cover crops (one with manure and one without) to a conventionally farmed corn/soy rotation, soil carbon levels (a proxy for soil organic matter) increased significantly, i.e., by 15.9 to $30 \%$ in the organic systems compared with no significant increase in the conventional system, after 15 years (Drinkwater et al. 1998). Using various indicators of soil organic matter in a quantitative synthesis of nine long-term study systems in the United States, Marriott and Wander (2006) similarly found that organic systems with legume cover crop rotations had significantly higher soil organic matter in surface soils than did paired conventional systems, irrespective of whether the organic treatment included manure.

Long-term trials also show that soils under organic management have greater abundance, diversity, and activity of soil microorganisms and macroorganisms responsible for nutrient cycling (Reganold et al. 1987, Mäder at al. 2002, Edmeades 2003). Further, using genetic techniques, Reganold et al. (2010) found that the abundance and diversity of functionally important genes involved in nitrogen, carbon, sulfur, and phosphorus transformations and cycling; metal reduction and resistance; and organic xenobiotic degradation were significantly greater on organic than conventional strawberry fields. Thus diversified farming system practices promote below-ground biodiversity, and this biodiversity in soils is probably a critical functional component of these farming systems, although this topic requires further exploration. In addition, soils under long-term organic management have improved physical, chemical, and biological properties. Specifically, percolation rates, aggregate stability, micronutrients, and root colonization by mycorrhizae fungi were all significantly higher in organic farming systems than in conventional farming systems (Reganold et al. 1987, Mäder et al. 2002, Edmeades 2003, Verbruggen et al. 2010), leading to better functional outcomes, such as reduced rates of soil erosion. For example, a 37-year- long trial revealed four-fold lower rates of annual water erosion on organic farms (8.3 ton/ha) than on conventional farms (32.4 ton/ha) (Reganold et al. 1987).

\section{Nutrient management}

Various diversified farming system practices increase the uptake of nutrients into crop biomass and/or soils, thus enhancing fertilizer use efficiency while reducing loss of nutrients to air and water, which are two critical agronomic and environmental management goals. Conventional agricultural systems, especially grains, have experienced dramatically declining fertilizer use efficiencies over several decades, requiring large increases in synthetic fertilizer application rates simply to maintain yields, with attendant increases in nutrient loss (Tilman et al. 2002, Miao et al. 2011). Loss of agricultural nitrogen and phosphorus to air and water cause severe environmental and human health problems, including eutrophication of fresh and marine waters, the emission of greenhouse gasses, and the depletion of stratospheric ozone (Tilman et al. 2002, Townsend et al. 2003, Diaz and Rosenberg 2008, Park et al. 2012). Thus diversified farming system practices can contribute simultaneously to efficient use of nutrients and to mitigation of point-source pollution.

Intercropping can increase nutrient use efficiency through several mechanisms, which may be particularly important in the tropics and sub-tropics where soils are naturally low in available nutrients. No meta-analysis was available on the effects of intercropping on nutrients; therefore we relied on reviews and primary studies. First, by growing crops with different rooting depths (including combinations of row and tree crops), the combined cropping system can exploit a larger soil volume and harvest nutrients (as well as water) from different soil strata (Hauggard-Neilsen and Jensen 2005). Crops that normally root at similar depths when planted as monocultures may root to different depths to avoid competition (e.g., pea and barley) when intercropped. Second, one crop can facilitate the uptake of nutrients by another crop. For example, in a field trial, Li et al. (2007) showed definitively that in a fava bean/maize intercrop, fava bean mobilized phosphorus that was taken up by maize, increasing maize yields by $43 \%$. Fava bean also over-yielded because its deeper root system allowed it to obtain nutrients not available to maize. Similarly, Knudsen et al. (2004) showed that grains intercropped with legumes used nitrogen resources more efficiently because the amount of $\mathrm{N}$ fixed by the legume increased relative to its $\mathrm{N}$-fixation in a sole-cropping system. Finally, improved nutrient use efficiency of combined cropping systems can produce a cobenefit of reducing soil nitrate loads and thus the potential for nitrate leaching (Zhang and Li 2003). 
Studying the effect of crop rotation on nutrient management, Gardner et al. (2009) conducted a meta-analysis of studies that followed the fate of ${ }^{15} \mathrm{~N}$ isotope tracer in crop biomass and soils (35 responses). They found that, relative to continuous cropping or simplified rotations such as corn/soy, more diverse rotations (including those with cover crops) significantly increased ${ }^{15} \mathrm{~N}$ recovery, i.e., by $17 \%$ in the grain cash crop alone and by $30 \%$ across all crops and soils. Comparing organic with inorganic sources of fertilizer (36 responses), it was further found that crops fertilized with legume residues and/or animal manures retained $72 \%$ more nitrogen in the grain crop by the second year than crops fertilized with inorganic $\mathrm{N}$, although this increased retention followed an initial reduction in retention in Year 1. (No significant differences in yield were found among systems in either year.) Overall, use of organic fertilizers increased ${ }^{15} \mathrm{~N}$ recovery by $42 \%$ in all crops and soils relative to inorganic fertilizer use. Further, they found that both complex crop rotations and use of organic fertilizers had significantly larger effects on retaining $\mathrm{N}$ in the system compared with several, but not all, practices typically used in conventional systems to manage nutrients. Specifically, these diversified farming system practices had greater effects than reducing $\mathrm{N}$ application rates $(N=86)$, using a nitrification inhibitor $(N=26)$ or improved chemical forms of synthetic $\mathrm{N}(N=22)$. Diversified farming system practices had equivalent effects to spring application of inorganic $\mathrm{N}(N=-18)$ or spatial targeting of inorganic $\mathrm{N}$ close to roots $(N=24)$. To conclude, the results of this meta-analysis suggest that diversified farming system practices can both enhance the uptake of $\mathrm{N}$ by the primary crop as well as reduce overall nutrient losses and pollution.

In comparing organic agriculture with conventional agriculture, Mondelaers et al. (2009) found, in a meta-analysis of 14 studies, significantly lower nitrate leaching for organic farming systems. The main drivers behind higher nitrate leaching in conventional farming systems include greater application rates of concentrated soluble fertilizers, lower use of cover crops that can scavenge residual soil $\mathrm{N}$, lower $\mathrm{C}$ to $\mathrm{N}$ ratio of fertilizers, and higher animal stocking densities per hectare (Mondelaers et al. 2009, Brennan and Boyd 2012). However, these results were heterogeneous, possibly due to among-study differences in soil type, farming system, region, study method, and time of measurement, and, according to the authors, should be interpreted cautiously. Further, while mean values of nitrate leaching from organic fields were less than half that of conventional, the two systems demonstrated near equivalence in nitrate leaching per unit of yield (due to the higher yields measured on conventional fields). In the same analysis, Mondelaers et al. (2009) found no significant differences in phosphorus loss between organic and conventional farming systems $(N=12)$. However, because phosphorus has low solubility and is primarily transported on soil particles, the demonstrated lower rates of soil erosion in diversified farming systems might result in reduced phosphorus pollution of surface waters (Tilman et al. 2002). While evidence that organic management per se reduces these pollutants sufficiently is weak (Mondelaers et al. 2009), use of organic management or other diversified farming system techniques (see above) at the field scale, in combination with landscape-scale diversified farming system practices such as vegetative buffers, should provide sufficient filtration to reduce nutrient pollution. In a quantitative synthesis of 73 studies, Zhang et al. (2010) found that vegetated buffers of 30 $\mathrm{m}$ removed $85 \%$ or more of nitrogen, phosphorus, sediment, and pesticide pollutants under favorable slope conditions.

At the global scale, both nitrogen and phosphorus are limiting resources for crop production, and any assessments of organic and conventional contributions to future food production must take into account the sourcing of these essential fertilizers. In conventional systems, use of synthetic nitrogenous fertilizers derived from the Haber-Bosch process have greatly expanded agricultural capacity, but production of synthetic fertilizers is energy intensive and could be limited in the next 50 to 100 years by diminishing supplies of fossil fuels (Crews and Peoples 2004). Organic systems obtain nitrogen through animal or green manures plus nitrogen fixation during intercropping or crop rotations. In a quantitative synthesis, Badgley et al. (2007) estimated that cover cropping with legumes between cropping cycles could provide sufficient nitrogen through biological fixation to support conversion to organic agriculture at the global scale. However, this estimate did not take into account geographic variation in temperature and water availability that would preclude use of off-season cover crops in some regions (Connor 2008). More cautious estimates of the capacity of leguminous cover crops to supply nitrogen requirements suggest that under selected scenarios, such as the reduction of food waste or the adoption of less meat-intensive diets, this farming practice could greatly reduce or eliminate dependence on synthetic nitrogen supplies (Crews and Peoples 2004). Mined phosphorus is projected to "peak" around 2030 (Cordell et al. 2009), affecting both organic and conventional production. However, some agroecological methods (i.e., intercropping, manuring, rotations, cover cropping with legumes) can improve phosphorus use efficiency or provide a source of recycled phosphorus to minimize the need for mined phosphorus ( $\mathrm{Li}$ et al. 2007, Conyers and Moody 2009). Therefore, diversified farming systems may be more resilient to peaking phosphorus supplies than conventional agriculture.

\section{Water-holding capacity}

The positive impact of diversified farming practices on soil organic matter content (Marriott and Wander 2006) can also lead to higher available water for plants (available water capacity) in surface soils, which may positively influence resistance and resilience of crop plants to drought conditions 
(Lotter et al. 2003, Weil and Magdoff 2004, Liu et al. 2007). Hudson (1994) has shown that in all soil texture groups, as soil organic matter content increased from 0.5 to $3 \%$, available water capacity more than doubled. In long-term trials measuring the relative water-holding capacity of soils, diversified farming systems have shown a clear advantage over conventional farming systems. For example, in a 37-year trial, Reganold et al. (1987) found significantly higher soil organic matter levels and $42 \%$ higher surface soil moisture content in organically managed plots than in conventional plots. In a 21-year study in Switzerland, Mäder et al. (2002) reported 20 to $40 \%$ higher water-holding capacity in organically managed soils than in conventionally managed soils. Recent research has suggested, however, that prior studies have not adequately measured the effects of agricultural practices like no-till and organic farming on soil organic matter in deeper soil layers (Dolan et al. 2006, Kravchencko and Roberts 2011, Syswerda et al. 2011). Therefore, although organic and no-till farming systems have clear advantages for soil organic matter accumulation (and thus water-holding capacity) in surface soils (Franzluebbers 2004, Marriott and Wander 2006), additional sampling at greater soil depths is an important, priority research area.

\section{Weed control}

Two central practices of diversified farming systems-crop rotation (temporal diversification) and intercropping (spatial diversification-can greatly suppress weed densities in comparison to monocultures (Barberi 2002). In a review of comparative studies assessing the effects of crop rotations versus monoculture on weeds, weed seed densities were found to be lower in $75 \%$ of the studies and equivalent in $25 \%$ (12 studies), while emerged weed densities were lower in $77.7 \%$ of the studies, higher in 3.7\%, and equivalent in 18.5\% (29 studies) (Liebman and Dyck 1993). The types of crops used in the rotation are critical, not only for weed management, but also to manage soil pathogens and fertility. For example, a rotation including a legume, row, sod, and cereal or grass crop provides, sequentially, nitrogen fixation for soil fertility, cultivation-stimulating weed germination, weed suppression due to smothering, and restoration of soil organic matter, and weed suppression due to allelopathy or high planting densities (Liebman and Dyck 1993). Additionally, the different crop types in the rotation collectively promote the development of more diverse weed communities but with fewer individuals per species (e.g., Sonoskie et al. 2006), thus potentially lessening the competitive effects on crop yield (Barberi 2002). In contrast, continuous monocropping can produce highly dense, locally adapted populations of single weed species that compete strongly with the crop (Barberi 2002).

Comparing intercropping versus monoculture, weed biomass was lower in $87 \%$, higher in $7.4 \%$, and variable in $5.5 \%$ of the 54 studies in which a main crop was intercropped with a "smother" crop, i.e., one purposefully introduced for weed control (Liebman and Dyck 1993). The intercropped weed suppressor also provides other benefits, such as forage, food, or nitrogen fixation, and examples show that such systems can be economically superior to sole crop systems (e.g., chickpea and wheat intercrop in India (Banik et al. 2006), and can provide equivalent yields to conventional monoculture with herbicide (e.g., Enache and Ilnicki 1990). Weed suppression was more variable when intercrops were composed of two or more main crops, rather than composed of a main crop and a smother crop. In comparison to monocultures of each crop, weed biomass was lower in the intercrop in $50 \%$ of the studies, intermediate in $41.6 \%$, and higher in $8.3 \%$ (24 studies; Liebman and Dyck 1993).

Increasingly, agroecological studies utilize multiple successive tactics to combat weeds, using knowledge of weed life cycles to identify strategies for control (Shennan 2008). For example, in the Great Plains of the United States, researchers aimed to reduce: (1) the seedbank, (2) seedling establishment, and (3) seed production of weeds by replacing a simple winter wheat fallow with a more complex rotation scheme. Within successive 2-year cycles of cool season crops (winter wheat or fallow) versus warm season crops (corn, sunflower, or proso millet), growers rotated crops to achieve varied planting and harvest dates, used a no-till system, and altered planting densities and timing to improve competitiveness of the crop. These combined tactics allowed growers to reduce herbicide applications by half and increase economic returns four-fold, due both to increased yields and lower input costs (Anderson 2005).

While weeds can reduce crop yields through competition with the crop, there are also known positive effects of weeds (Shennan 2008). Weeds can draw pests away from crops. Or they can provide habitat and floral resources for natural enemies that control pests (Norris and Kogan 2005), for pollinator species that provide crop pollination (Carvalheiro et al. 2011), and for other biodiversity (Marshall et al. 2003). They can provide important food or medicinal resources for humans in or around crop fields (e.g., purslane (Altieri et al. 1987)). Conventional cropping systems generally maintain much lower weed abundance than organic systems (Gabriel et al. 2006).

Alternatively, weeds can enhance pests or diseases and/or reduce the effectiveness of ecosystem service providers, for example by competing with crops for pollination services. Given the multiple interactions between weeds, other pests or diseases, and ecosystem service providers, it is clear that the study of weed management cannot occur in isolation from other components of the farming system. Whole-system, integrative studies of diversified agriculture are needed in order to effectively support multifunctional agriculture (e.g., Box 1; Norris and Kogan 2005, Shennan 2008, Tomich et al. 2011). 
Box 1. The push-pull system for control of pests of corn and sorghum in Africa

Researchers worked in East Africa for the last 15 years to develop an agroecological pest-management solution for stem borers and striga weed, two major pests of maize and sorghum, crops on which millions of the poorest people in eastern and southern Africa rely (Khan et al. 2011). Yield losses to stem borers typically range from 20 to $40 \%$ but can reach $80 \%$, while losses from striga are even higher, and when these pests co-occur, farmers can lose their entire crop (Khan et al. 2000). The push-pull method developed by researchers manages stem borer pests through a stimulo-deterrent chemical ecology strategy. Selected fodder species and wild grasses are intercropped in maize fields to "push" stem borer pests from the system, while other grasses are used as trap crops to "pull" the stem borers away, protecting the crop from infestation (Shelton and Badenes-Perez 2006). Intercropped plants that not only repel stem borers but also attract natural enemies can further decrease stem borer densities by enhancing parasitism rates (Khan et al. 1997). Two leguminous plants, Desmodium uncinatum and D. intortum, are also intercropped; these fix nitrogen and produce root exudates that limit the reproductive success of striga weed (Khan et al. 2000). In addition to enhancing crop yields, the push-pull strategy has been shown to improve small livestock production, conserve soil resources, enhance functional biodiversity, and increase incomes and women's empowerment (Khan and Pickett 2004). As of 2010, the push-pull system has been adopted by over 30,000 smallholder farmers in east Africa, where maize yields have increased by 1 to $3.5 \mathrm{t} / \mathrm{ha}$, on average, with minimal external inputs (Khan et al. 2011).

\section{Disease control}

In a large-scale study in China, Zhu et al. (2000) showed that, compared with monoculture, interplanting resistant rice varieties with disease-susceptible varieties produced $89 \%$ greater yield and reduced rice blast disease, which is caused by aerial fungal pathogens, by $94 \%$ in susceptible varieties. By the second year of the project, growers no longer utilized foliar fungicides and the program expanded from 3000 to 40,000 ha. Similarly, in the former eastern Germany, mixed cultivars of barley were used to suppress powdery mildew disease, and disease incidence and fungicide use dropped by $80 \%$ while the area of mixed cultivation expanded to 350,000 ha over a 6-year period (see also other examples in de Vallavielle-Pope 2004).

Further, for soilborne or splashborne diseases, Hiddink et al. (2010) found that mixed cropping systems (including strip intercropping, row intercropping, relay intercropping, and intercropping of genetic variants) reduced disease in $74.5 \%$ of cases in comparison to monoculture (19.6\% neutral; $5.9 \%$ negative; in a vote count of 36 studies comprising 51 comparisons). Host dilution was frequently proposed as the mechanism for reducing disease incidence of both soilborne and splash-dispersed pathogens. Other mechanisms, such as allelopathy and microbial antagonists, are thought to affect disease severity in diversified farming systems (Stone et al. 2004). Although these results are encouraging, in most cases levels of disease suppression were relatively modest $(<50 \%)$ compared with the sole crop, and thus while reduced, soil pathogens could still depress yields significantly in intercrops. In a few cases, mixed cropping resulted in complete elimination of the disease (e.g., Zewde et al. 2007). The effectiveness of disease suppression is likely to be greatly influenced both by the spacing and types of crops in the mixed cropping system. For example, strip intercropping provides fewer opportunities for interactions between crop roots than row intercropping. Further, root architecture of component crops influences the degree of interactions with one another and the microbial community, and thus the rate of disease spread.

Although use of mixed-crop strategies is not yet a reliable strategy for control of soil pathogens (although it is promising and warrants more investigation), crop rotations are already widely utilized for management of soil pathogens, within both small-scale and industrial agriculture (e.g., corn/soybean rotation in the Midwest United States). Crop rotations are widely understood to interrupt the build-up of soil pathogens, diseases vectors, and other pests while making more efficient use of available nitrogen (Bezdicek and Granatstein 1989, Francis 2004, see also Shennan et al. 2009). However, for certain crop-pathogen combinations (e.g., Gaeumannomyces graminis and wheat), continuous monocropping ultimately induces natural disease suppression, and crop rotation interrupts this process, thus increasing disease incidence (Hiddink et al. 2010). In induced resistance, prior exposure to a pathogen or parasite results in resistance against subsequent challenges by the same pathogen or parasite (Vallad and Goodman 2004). Diversified farming system practices have not been shown to consistently induce disease resistance across a wide range of crops (Tamm et al. 2011), despite their positive effects on disease prevention and suppression (see above) and on soil quality (Liu et al. 2007, Birkhofer et al. 2008, Verbruggen et al. 2010). Moreover, in a recent study of the impact of short-term and long-term soil fertility management strategies on induced suppression of airborne and soilborne diseases, Tamm et al. (2011) found that site-specific physical factors such as soil type (i.e., those not influenced by agronomic practices) had a greater impact than agronomic practices.

In conclusion, while mixed cropping and crop rotation strategies appear to be among the few viable economic alternatives to chemical control of above-ground and belowground crop pathogens, far more work remains to be done to design consistently effective disease management systems (Hiddink et al. 2010). Furthermore, given that mixed cropping and crop rotation practices influence many ecosystem 
processes and services (Table 1), it is clear that in order to develop cost-effective diversification strategies, wholesystem agroecological studies that consider multiple interactions simultaneously are needed (Shennan 2008, Tomich et al. 2011).

\section{Arthropod pest control}

Over the last 40 years, many studies have evaluated the effects of local-scale (i.e., field-level) diversity on densities of herbivore pests (Andow 1991, Altieri and Nicholls 2004). Meta-analyses suggest that diversification schemes generally achieve significant positive outcomes including natural enemy enhancement, reduction of herbivore abundance, and reduction of crop damage, from a combination of bottom-up and top-down effects (Letourneau et al. 2011). Specifically, in a meta-analysis of 21 studies comparing pest suppression in polyculture versus monoculture, Tonhasca and Byrne (1994) found that polycultures significantly reduced pest densities by $64 \%$. In a later meta-analysis with a nonoverlapping set of studies (45 articles comprising 552 total comparisons), Letourneau et al. (2011) found a $44 \%$ increase in abundance of natural enemies (148 comparisons), a 54\% increase in herbivore mortality (221 comparisons), and a 23\% reduction in crop damage (99 comparisons) on farms with species-rich vegetational diversification systems (including within or around the field) than on farms with species-poor systems. There were relatively fewer comparisons of yield (87); crop diversity exhibited a negative effect on yield when experiments were substitutive (replacing crop plants on which yield measurements were based with other plants), but had a significant positive effect when experiments were additive (Letourneau et al. 2011).

Other local-scale studies have compared pest-control services on organic farms and conventional farms and related these services to the structure of the arthropod community. For tomatoes, organic farms displayed an entirely different arthropod community structure than did conventional farms, with higher species richness for both pests and natural enemies, and higher abundance of natural enemies (Letourneau and Goldstein 2001). However, no differences were found between these same farms in the level of damage by arthropod pests, which the authors interpreted as evidence that natural enemies provided a pest-control service on these organic fields equivalent to that established through pesticide use on conventional fields (Drinkwater et al. 1995). (Not all organic growers relied solely on control provided by natural enemies, however; several used allowed organic treatments such as soap sprays and Bacillus thurigensis). No metaanalysis of studies examining pest control on organic crops versus conventional crops yet exists (Letourneau and Bothwell 2008). To assess the generality of the relationship found between natural enemy richness and damage levels found in the tomato study, Letourneau et al. (2009) instead conducted a meta-analysis of 62 studies in natural areas (100 comparisons) and agricultural areas (126 comparisons); they obtained a significant positive relationship between the species richness of natural enemies and the level of herbivore suppression both overall and in agricultural areas alone. In experimental work, Crowder et al. (2010) found that community evenness, i.e., the distribution of abundances of species in a community, rather than richness of arthropod natural enemies (above ground) and pathogens (below ground), was critical in determining the level of pest suppression of the potato beetle (Leptinotarsa decemlineata), and that organic fields had significantly higher evenness than conventional fields, both in the potato system, and in a metaanalysis of 38 studies (48 comparisons). Thus, farming practices that encourage species richness, such as winter cover cropping (Letourneau and Goldstein 2001), landscape-scale diversification (Geiger et al. 2010), or reduced pesticide use (Drinkwater et al. 1995, Bengtsson et al. 2005, Attwood et al. 2008, Geiger et al. 2010), may all contribute to development of arthropod communities with the potential to provide more effective pest-control services (Letourneau et al. 2009, Crowder et al. 2010).

Most field-scale biological control studies conducted prior to circa 2000 failed to measure the influence of the surrounding landscape on pest regulation (Bianchi et al. 2006), but recent studies have shown that landscape complexity-the quality and quantity of noncrop vegetation around a farm-can significantly affect pest control (Thies and Tscharntke 1999, Thies et al. 2005, Gardiner et al. 2009). However, a recent meta-analysis of pest-control studies (23 studies with 41 responses) comparing sites in differing landscape contexts found that there were no significant effects for pest responses (abundance, crop damage) even though natural enemy abundance, diversity, and predation or parasitism rates increased significantly on average with landscape complexity (38 studies with 118 responses (Chaplin-Kramer et al. 2011)). The lack of a consistent pest response to landscape complexity may be due to the paucity of studies that have measured pest responses at the landscape scale; further research is needed. Alternatively, while the more abundant and diverse natural enemy communities found in complex landscapes (ChaplinKramer et al. 2011) may result in greater pest suppression (Letourneau et al. 2009), these effects may be masked by greater overall pest abundances in such landscapes (Thies et al. 2005, Chaplin-Kramer et al. 2011). Thus greater pest control may be occurring in such landscapes, but it may not have been detected.

Several recent large-scale pest-control studies, however, do detect the effects of diversified farming practices at the landscape scale. Geiger et al. (2010), working on 270 cereal fields in nine regions of Europe, found that the potential for pest control (measured as the mean survival time of aphids placed at each site) was positively correlated with the percentage of the surrounding landscape using agri- 
environment management practices, and was negatively correlated with the amounts of active ingredient of pesticide applied at the site. Meehan et al. (2011), in a study covering seven states in the Midwestern United States, estimated that growers incurred substantially higher costs due to the loss of natural habitat, and due to decreased yields and increased insecticide applications. The cost equaled US $\$ 48 /$ ha of agricultural land and totaled US\$34 to 103 million dollars/ year over the entire region. In conclusion, there is significant evidence that local-scale vegetation diversity enhances pest control by a modest amount (Letourneau et al. 2011), and there is growing evidence of landscape-level effects (Geiger et al. 2010, Meehan et al. 2011). Most importantly, for many systems, there is still limited empirical information to guide growers on how best to utilize diversified farming techniques to consistently regulate arthropod pest populations below economic thresholds; such work is highly system specific, requiring detailed agroecological investigation (e.g., Vandermeer et al. 2010, and see the sidebar). Such detailed investigations should be a high priority for research funding.

\section{Pollination services}

Both meta-analysis and quantitative syntheses across multiple crop types and biomes strongly show that wild pollinator communities decrease significantly in abundance and richness in agricultural landscapes with extreme habitat loss or increased distance to natural habitat (meta-analyses: Ricketts et al. 2008, 23 studies; Winfree et al. 2009, 54 studies) (quantitative synthesis: Garibaldi et al. 2011, 29 studies). These landscape effects on wild pollinator communities translate to small but significant reductions in the magnitude and stability of pollination services provided to crops (mean of -16 and $-9 \%$ respectively at $1-\mathrm{km}$ isolation from natural habitat), despite the ubiquity of managed honey bees which have been brought into farming landscapes explicitly to provide pollination services (Garibaldi et al. 2011). Managed honey bees have also suffered in recent years from various diseases, pesticides, and other environmental stresses, and are in decline in many countries around the globe (Neumann and Carreck 2010); therefore the contributions of wild pollinators to crop pollination (comprised of many other bee species as well as other insects) have taken on new significance (Klein et al. 2007, Potts et al. 2010, Eilers et al. 2011).

As with other components of biodiversity, pollinator communities were richer and more abundant with agrienvironment management schemes (primarily organic), but this effect was only significant in simple landscapes $(<20 \%$ seminatural habitats) (meta-analysis: Batáry et al. 2011; abundance, 11 studies; richness, 13 studies). Several studies have shown that organic management can have a positive effect on pollinator richness and abundance at both the local and landscape scales (Holzschuh et al. 2008, Gabriel et al. 2010). In 42 wheat fields studied in three widely separated regions of Germany, organic management increased the richness of pollinators by $60 \%$ and abundance by 130 to $136 \%$ (depending on the taxon) relative to that in conventional fields. In addition to this local effect, increasing the proportion of organic fields in the landscape from 5 to $20 \%$ further increased pollinator richness and abundance by $>60 \%$ on both organic and conventional farm fields. The authors attributed these spillover effects to the enhancement of the diversity and abundance of floral resources in the organic fields that provide nectar and pollen for pollinator species, rather than to the reduction of insecticide use (Holzschuh et al. 2007, 2008). An effective management technique for enhancing pollinator richness and abundance on farms is to plant flower-rich hedgerows, grassy borders, or in-field insectary strips (e.g., Potts et al. 2009), although it is not yet known whether such techniques simply concentrate existing pollinators at the floral resources, or increase pollinator population sizes, thus potentially enhancing pollination services in adjacent crop fields.

Differences in bee communities due to local management can translate into differences in pollination services provided; in Canada, an experimental study revealed that seed set was on average 3 to 6 times lower on conventional and GMO canola fields using insecticides and herbicides than on organic fields, and this reduced seed set was strongly correlated with reduced abundances of native pollinators (Morandin and Winston 2005). There are still relatively few studies, however, that have measured the effects of local-scale management actions on pollination services. In those studies that do, landscape-scale variables overshadow the effects of local-scale management (e.g., Kremen et al. 2002, Carvalheiro et al. 2010). Thus there is a need for additional highly replicated studies that examine both local and landscape factors (such as those conducted by Holzschuh et al. 2008 and Gabriel et al. 2010) and that study not only pollinator communities but also pollination services.

\section{Carbon sequestration}

Soils contain the largest pool of carbon actively turning over in the global carbon cycle (Weil and Magdoff 2004). Transformation of natural habitats to agriculture reduces soil carbon and is a major contributor to greenhouse gas emissions (Fargione et al. 2008). However, through proper management, Lal (2004) estimates that the world's agricultural soils have the potential to absorb an estimated 50 to $66 \%$ of the historic loss of 55 to 78 gigatons of carbon caused by prior conversion of natural habitats, and to mitigate an estimated 5 to $15 \%$ of annual global fossil fuel emissions. Agronomic practices thought to significantly increase the storage of soil carbon include practices that reduce disturbance and/or practices that increase organic inputs to the soil. Those include no-till, lowtill, and perennial-based agriculture, cover cropping, fallow rotations, application of manures, green manures or composts, improved grazing practices, efficient irrigation, agroforestry, and the regeneration of woodlands ( $\mathrm{Lal} 2004)$. Some of these 
practices enhance vegetative diversity (e.g., agroforestry) while others enhance soil biodiversity (manures and compost).

Earlier work suggested that reduced or no-till agriculture would have the largest effects on carbon sequestration (Lal 2004), because it tends to enhance soil carbon in the surface layers of the soils (e.g., by a mean of $31 \pm 6.4$ (SE) g/m $/ \mathrm{m}^{2} / \mathrm{y}$, 136 studies (Franzluebbers 2004)). However, such conclusions have since been questioned, because the sampling of soils under different management regimes may frequently be too limited to permit detection of significant differences (Kravchenko and Roberts 2011). Limited sampling is especially problematic in the deeper soil layers, where the amounts of carbon stored are both smaller and more variable (Syswerda et al. 2011). Knowledge about carbon stored in the deeper layers is particularly important, because management practices that enhance carbon in surface layers, such as no till or low till, may actually reduce carbon storage at deeper layers (i.e., by reducing the incorporation and decomposition of plant materials and subsequent root growth), leading to no net difference in stored carbon between management practices (Dolan et al. 2006, Franzluebbers 2004). Further study of how diversified farming system practices influence soil carbon up to a 1-m soil depth is merited, not only to assess the potential of agricultural soils to mitigate greenhouse gases, but because increasing soil carbon can enhance a wide range of ecological services including increased food production (e.g., increases of 1 ton/ha in degraded croplands can double yields of staple crops like wheat and corn (Lal 2004). Again, a holistic perspective is needed, because farming practices that affect soil organic carbon influence multiple ecosystem services simultaneously. For example, while no-till agriculture may not result in a net increase in carbon sequestration when deeper soil layers are considered, no-till or low-till agriculture can protect surface soils from erosion, promote water infiltration, and, over time, increase soil fertility by enhancing nitrogen stocks (Franzluebbers 2004).

\section{Energy-use efficiency and reduction of global-warming potential}

Over the last 15 years, many attempts have been made to measure the global-warming potential of conventional and diversified farming systems by calculating relative energy use, energy-use efficiency, and the outputs of key greenhouse gasses including carbon dioxide $\left(\mathrm{CO}_{2}\right)$, methane $\left(\mathrm{CH}_{4}\right)$, and/ or nitrous oxide $\left(\mathrm{N}_{2} \mathrm{O}\right)$ (Lynch et al. 2011). In a major review of approximately 130 studies, Lynch et al. (2011) analyzed farm-level energy use and global-warming potential of organic and conventional farming systems, including field, fruit, and vegetable crops, and beef, hog, poultry, and dairy production. In general, organic farming systems had significantly lower energy use and greenhouse gas emissions per hectare, and higher energy efficiency (energy input/output) per unit of product. These differences exceeded, often by a substantial margin, the $20 \%$ threshold set by the authors as a minimum level needed for policy action. Avoidance of synthetic nitrogen fertilizers, which require large amounts of energy to produce (Pelletier et al. 2011), and lower use of feed concentrates, were largely responsible for the improved energy performance of the organic farming systems per unit of land or product. Results were more variable for global-warming potential than for energy indicators, however, due in part to large uncertainties in the measurement of $\mathrm{N}_{2} \mathrm{O}$ emissions from soils and manure. In some studies, especially those of hog, poultry, and dairy production, organic methods produced higher emissions per unit of product, often due to lower rates of feed conversion. Contrary to expectations, increased tillage in organic farming systems for weed control and crop rotations was not a significant contributor to on-farm energy use, nor did these practices lead to net reductions in soil carbon, due to the mitigating effects of green manures (Lynch et al. 2011).

\section{Resiliency to environmental disturbances: severe weather conditions}

Recent research has demonstrated that diversified farming systems exhibit greater levels of resilience to environmental disturbances across multiple ecosystem services and thus may serve as a cost-effective adaptation strategy in the face of global climate change (Lin 2011, Tengo and Belfrage 2004). The enhanced soil quality of diversified farms (see above) can improve key soil functions such as water storage and infiltration, thereby increasing ground-water recharge while reducing surface run-off and erosion (Weil and Magdoff 2004, Pimentel et al. 2005), and thus enhancing the resiliency of the farming system to droughts and deluges. For example, over a 5 -year period that included three drought years, legume and legume+manure-based organic systems from the 21-year Rodale trial captured, respectively, 16 to $25 \%$ more water than the conventional system (Lotter et al. 2003). In four of five drought years, maize yield was significantly greater in organic systems than in conventional systems. In the most extreme drought year, mean corn yields were $137 \%$ higher in the legume+manure-based organic system than in the conventional system (but were reduced relative to conventional in the legume treatment due to weed competition), while mean soybean yields were 196\% (and $152 \%$ ) higher. The enhanced water storage and infiltration properties of organic soils also improved the response to an extreme rainfall event. Water capture in the organic plots was approximately double that in the conventional plots, indicating higher rates of percolation, lower volumes of surface runoff, and reduced rates of erosion (Lotter et al. 2003, Pimentel et al. 2005).

Lin (2007) showed that more structurally complex (i.e., diversified) coffee-farming systems limited extreme temperature fluctuations and kept crops closer to ideal growing conditions when contrasted with low-shade coffee systems in Chiapas, Mexico. Further, multistory high-shade systems 
better protected crops from water stress during drought periods due to reduced evaporation and improved soil infiltration rates (Lin et al. 2008).

Using a participatory research approach, Holt-Giménez (2002) found significant differences in the resistance and resilience of conventional and diversified farming systems in Nicaragua following Hurricane Mitch (October 1998). On 880 paired plots in 181 separate communities, diversified farms were found to have a $49 \%$ lower incidence of landslides, $18 \%$ less arable land loss to landslides, $20 \%$ more vegetative cover, $47 \%$ less rill erosion, $69 \%$ less gully erosion, and $40 \%$ more topsoil compared with conventional farms. Following Hurricane Mitch, diversified farms suffered lower economic losses than conventional farms. The enhanced resistance and resilience of diversified plots was more pronounced with increasing levels of storm intensity, slope, and number of years under diversified farming practices. Similarly, Philpott et al. (2008b) found that coffee farms managed for greater vegetative complexity experienced fewer landslides during Hurricane Stan (October 2005) in Chiapas, Mexico, although this did not translate into economic differences among farm management types given that few landslides occurred within the coffee-production regions of the farms. Rosset et al. (2011) found that farms with greater "agroecological integration" recovered more rapidly from hurricane disturbance in Cuba.

\section{Crop yield}

Badgley et al. (2007) conducted a quantitative synthesis of studies measuring the relative yields of organic and conventional farms across many cropping systems. In developed nations they found that crop yields were $8.6 \%$ lower for organic systems than for conventional systems (with a 95\% confidence interval of 4.7 to $12.5 \%$, based on 138 comparisons in 43 studies). In developing nations, they found a mean yield increase of $174.6 \%$ (with a $95 \%$ confidence interval of 156.0 to $191.2 \%$ ) when diversified farming practices were employed, compared with resource-poor (generally subsistence) farming strategies (138 comparisons from 29 studies). These results were contested, however, by authors who suggested that organic management would produce similar yields only if off-farm sources of manure were utilized, or when utilizing leguminous noncrop rotations that would decrease overall yields over the full crop rotation cycle (Kirchmann et al. 2008). Subsequently, two new studies (de Ponti et al. 2012, Seufert et al. 2012) critiqued the Badgley et al. (2007) study, primarily based on the choice of studies included in the Badgley study. Based on data quality criteria and a stricter definition of organic and conventional systems, De Ponti et al. (2012) rejected $86 \%$ of the studies utilized by Badgley et al. (2007); in their quantitative synthesis, they found an average $20 \%$ (with a $95 \%$ confidence interval of 17.8 to $22.2 \%$ ) yield gap (based on 362 comparisons from 135 studies post 2004). Seufert et al. (2012) conducted a metaanalysis utilizing an overlapping but different set of studies than those used by de Ponti et al. (2012). While also requiring a strict definition of organic versus conventional, the metaanalysis further required that studies report both a mean and error term, resulting in 316 comparisons from 66 studies. Seufert et al. found an overall yield gap of 25\% (with a 95\% confidence interval from 21 to 29\%) (Seufert et al. 2012). L. Ponisio and C. Kremen (personal observation) noted that Seufert et al. (2012) used some yield data as the baseline for multiple comparisons (more than $50 \%$ of observations), which might result in an overestimate of the size and significance of differences between organic and conventional yields. The question of how organic and conventional yields compare is still uncertain due to the small number of available studies that present appropriate data for making this comparison; this is a key area for additional research.

Conclusions varied widely among the de Ponti et al. (2012), Seufert et al. (2012), and Badgley et al. (2007) studies regarding differences in yield gaps among developed and developing countries. Most of the data in the Seufert et al. and de Ponti et al. analyses were from the developed world ( 80 to $90 \%$ ), whereas the Badgley et al. (2007) study included a larger proportion of responses from developing countries (45\%). Seufert et al. found a significantly greater yield gap for developing (43\%) than developed $(20 \%)$ countries, whereas de Ponti et al. found a slight, but nonsignificant, reduction in yield gap for developing countries relative to developed. Seufert et al. attributed their finding of a larger yield gap in developing countries to the atypically high conventional yields found in those studies, relative to local averages. In contrast, Badgley et al. found a large yield gain for organic systems in developing countries (174\%). The switch from yield gain to yield loss between the Badgley et al. and the other studies can be attributed to the different ways in which each study drew comparisons among farming systems. The two recent papers utilized strict definitions of organic and conventional systems. In contrast, Badgley et al. compared resource-conserving agroecological methods that were not necessarily strictly organic against subsistence or low-input conventional systems, rather than against high input conventional methods. The results in Badgley et al. therefore imply that widespread implementation of diversified farming systems by smallholders in developing countries might result in substantial gains for global food production because, by one estimate, $50 \%$ of smallholders in developing nations do not currently use resource-conserving practices (Altieri and Toledo 2011). However, many of the studies from developing countries utilized by Badgley et al. (2007) lacked appropriate controls, and therefore we lack a strong quantitative assessment of the potential for diversified farming systems to enhance food production in developing countries (Seufert et al. 2012).

Other management factors may modify the organic to conventional yield gap, such as the length of time under 
organic management. For some management systems or crops, organic yields nearly rival conventional yields (Seufert et al. 2012; L. Ponisio and C. Kremen personal observation). Several factors that could influence the relative yields have not been taken into account in any global assessment. First, organic management can produce higher yields than conventional management under extreme climate conditions such as drought or deluge (Lotter et al. 2003, Pimentel et al. 2005). Second, most primary studies did not utilize intercropping as an organic farming practice (e.g., $<25 \%$ of the studies in Seufert et al. 2012). The reported organic to conventional yield losses could potentially be reduced or eliminated if organic farming systems utilized intercropping strategies (e.g., grain and legume or other combinations) that promote over-yielding (Vandermeer 1992, Snapp et al. 1998, Li et al. 2007). Third, an estimated $95 \%$ of organic agriculture uses crop varieties bred for conventional production systems (i.e., selective breeding in environments with synthetic fertilizers and pesticides). Yet, recent studies have shown that such varieties lack important traits (e.g., pest and disease resistance) to produce optimally under organic and/or lowinput production conditions. Their use by organic producers may negatively affect nutrient use efficiency, tolerance for mechanical weed control, pest resistance and crop nutrition, thereby reducing crop yield in organic systems (Murphy et al. 2007, Lammerts van Bueren et al. 2011) and contributing to the reported organic to conventional yield gap. Local, regional, and global-scale quantitative comparisons that integrate these important factors are therefore needed to develop a more accurate assessment of the yield loss (or gain) effects of diversified farming systems. Importantly, future comparisons should assess the total human-edible calorie or net energy yield of the entire basket of crops produced over a complete rotation, rather than the yield ratios from single crops (Seufert et al. 2012), given that rotational and intercropping strategies are essential components of farming systems, especially diversified farming systems. In addition, there is a huge need for well-designed comparisons of yield between diversified farming systems and conventional systems that report both means and variances (L. Ponisio and C. Kremen personal observation).

\section{Trade-offs between crop productivity and biodiversity conservation}

If diversified farming systems are less productive in yield per area than conventional monoculture systems, the widespread adoption of such agriculture could require a larger land area to produce the same amount of food, potentially causing more habitat conversion and loss of biodiversity in order to feed the global population (Green et al. 2005, Phalan et al. 2011). The empirical evidence in favor of this "land-sparing" argument, however, is equivocal on two fronts: (1) that diversified farming systems reduce yields per area, or (2) that enhancing yields through industrialized agriculture results in the conservation of land for biodiversity. In addressing the first point, mean yield losses from a diversified farming system can be relatively small and might be reduced or eradicated by intercropping and through greater investment in research and development (see above). In addition, small farms are generally more productive in total output per hectare than larger farms, and this relationship is attributed in part to the diversified nature of smaller farms and their resource intensive use of land (reviewed in Rosset 1999). Further, as illustrated above, the use of appropriate diversified farming systems might increase, not decrease, yields for the substantial fraction of the global population in the developing world that currently practice low-input subsistence techniques (Pretty et al. 2006). Thus the use of diversified farming systems could potentially be a strategy for increasing production and local food security, particularly in biodiversity hotspot areas (Cincotta et al. 2000), which in turn could potentially reduce the need for habitat conversion and reduce attendant biodiversity loss (Phalan et al. 2011). In addressing the second point, a recent global analysis showed that increased yields per area do not consistently translate into reduced crop areas or reduced habitat conversion (Rudel et al. 2009, see also Perfecto and Vandermeer 2010). In contrast, high-yielding conventional monocultures are a known leading cause of forest conversion in several biodiversity hotspots, including the Brazilian Amazon (soy, Morton et al. 2006) and the rainforests of southeast Asia (oil palm, Wilcove and Koh 2010), representing a shift from earlier deforestation pressure from smallholders (Rudel 2007, DeFries et al. 2010). We conclude that broader adoption of diversified farming systems is not likely to provoke greater forest conversion than conventional monoculture agriculture, but that more complete quantitative comparisons of total output per area between diversified farming systems and conventional monoculture are critically needed in various crops, regions, and production systems around the world.

\section{CONCLUSIONS}

Increased production is often cited as the main requirement for feeding a growing, changing world (Godfray et al. 2010), even though there is increasing consensus that it is problems of distribution and access that are responsible for the 1 billion hungry people today (IAAKSTD 2009). Production is also the primary goal of many growers working under small profit margins. In many industrialized systems, food production clearly trades off against other ecosystem services produced on agricultural lands (Foley et al. 2005), and is responsible for many negative environmental costs (Pimentel 2009, Gomiero et al. 2011a) and social costs (Villarejo 2003, Marks et al. 2010, Pimentel 2010). Indeed, while food production has greatly increased over the past 50 years under the industrialized model of the Green Revolution, most regulating and supporting ecosystem services have correspondingly 
declined (Millennium Ecosystem Assessment 2005, Raudsepp-Hearne et al. 2010).

Our review suggests that it is possible to design many diversified farming systems that are equally productive and that maintain or enhance the provisioning of ecosystem services and thus agroecosystem resilience and sustainability. We found substantial evidence to support significant advantages of biologically diversified farming systems for biodiversity conservation, control of arthropod pests, weeds and diseases, pollination services, soil quality maintenance, energy-use efficiency and reduction of global-warming potential, resistance and resilience of farming systems to extreme weather events, and enhanced carbon sequestration and water-holding capacity in surface soils (see also Gomiero et al. 2011b). Additionally, diversified farming systems have been able to outperform conventional farming systems across a wide range of key ecological services despite receiving a small fraction of the research and development dollars allocated to conventional agriculture (Lipson 1997, Sooby 2001, Vanloqueren 2009). Nonetheless, much work remains to be done; in particular, integrated whole-system studies of the influence of different farming practices on multiple ecosystem components and services are critically needed in order to design optimal farming systems for specific regions, and to reduce yield gaps (Badgley et al. 2007, de Ponti et al. 2012, Seufert et al. 2012), when they exist, between diversified farming systems and conventional cropping systems.

Although some diversified farming systems may not currently be as productive per hectare as chemically based conventional agriculture (de Ponti et al. 2012), we note that lower productivity can be balanced by enhanced environmental benefits and reduced externalities of diversified farming systems. In addition, there are many other important mechanisms for ensuring the human food supply that do not require enhancing crop productivity per area-for example, reducing food wastage (currently at 40\%), changing consumption patterns towards a vegetarian diet, reducing biofuels production, and regulating commodity speculation, among others (Crews and Peoples 2004, Foley et al. 2011, Food and Agriculture Organization 2011). Further, we argue that with significantly increased investment in research and development, the scientific and agricultural communities would realize both greater ecological performance and food production from diversified farming systems. Choosing to invest in diversified farming systems, as opposed to continued investment in biotechnology and other reductionist strategies, is the right choice for developing sustainable farming systems and livelihoods.

Responses to this article can be read online at: http://www.ecologyandsociety.org/issues/responses. php/5035

\section{Acknowledgments:}

We are grateful to two anonymous reviewers, and to Tim Crews, Rebecca Chaplin-Kramer, Alastair Iles, Matthew Luskin, Celine Pallud, and members of the Diversified Farming Systems Working Group at University of California Berkeley, for comments on the manuscript. The Berkeley Institute of the Environment and the Neckowitz Family Foundation provided support for the series of Diversified Farming Systems Roundtables that led to this paper.

\section{LITERATURE CITED}

Altieri, M. A. 2004. Linking ecologists and traditional farmers in the search for sustainable agriculture. Frontiers in Ecology and the Environment 2(1):35-42.

Altieri, M. A., M. K. Anderson, and L. C. Merrick. 1987. Peasant agriculture and the conservation of crop and wild plant resources. Conservation Biology:49-58. http://dx.doi. org/10.1111/j.1523-1739.1987.tb00008.x

Altieri, M. A., and C. I. Nicholls. 2004. Biodiversity and pest management in agroecosystems. Food Products Press, Binghamton, New York, USA.

Altieri, M. A., and V. M. Toledo. 2011. The agroecological revolution in Latin America: rescuing nature, ensuring food sovereignty and empowering peasants. Journal of Peasant Studies 38(3):587-612. http://dx.doi.org/10.1080/03066150.$\underline{2011.582947}$

Anand, M., J. Krishnaswamy, A. Kumar, and A. Bali. 2010. Sustaining biodiversity conservation in human-modified landscapes in the Western Ghats: remnant forests matter. Biological Conservation 143(10):2363-2374. http://dx.doi. org/10.1016/j.biocon.2010.01.013

Anderson, R. 2005. A multi-tactic approach to manage weed population dynamics in crop rotations. Agronomy Journal 97 (6):1579-1583. http://dx.doi.org/10.2134/agronj2005.0194

Andow, D. 1991. Vegetational diversity and arthropod population response. Annual Review of Entomology 36:561-586. http://dx.doi.org/10.1146/annurev.en.36.010191.003021

Attwood, S., M. Maron, A. House, and C. Zammit. 2008. Do arthropod assemblages display globally consistent responses to intensified agricultural land use and management? Global Ecology and Biogeography 17(5):585-599.

Bacon, C. M., C. Getz, S. Kraus, M. Montenegro, and K. Holland. 2012. The social dimensions of sustainability and change in diversified farming systems. Ecology and Society 17(4): 41. http://dx.doi.org/10.5751/ES-05226-170441

Badgley, C., J. Moghtader, E. Quintero, E. Zakem, M. J. Chappell, K. Aviles-Vazquez, A. Samulon, and I. Perfecto. 
2007. Organic agriculture and the global food supply. Renewable Agriculture and Food Systems 22(02):86-108. http://dx.doi.org/10.1017/S1742170507001640

Banik, P., A. Midya, B. Sarkar, and S. Ghose. 2006. Wheat and chickpea intercropping systems in an additive series experiment: advantages and weed smothering. European Journal of Agronomy 24(4):325-332. http://dx.doi.org/10.1016/ j.eja.2005.10.010

Barberi, P. 2002. Weed management in organic agriculture: are we addressing the right issues? Weed Research 42 (3):177-193.

Batáry, P., A. Báldi, D. Kleijn, and T. Tscharntke. 2011. Landscape-moderated biodiversity effects of agri-environmental management: a meta-analysis. Proceedings of the Royal Society B-Biological Sciences 278(1713):1894-1902. http:// dx.doi.org/10.1098/rspb.2010.1923

Batáry, P., T. Matthiesen, and T. Tscharntke. 2010. Landscape-moderated importance of hedges in conserving farmland bird diversity of organic vs. conventional croplands and grasslands. Biological Conservation 143(9):2020-2027. http://dx.doi.org/10.1016/j.biocon.2010.05.005

Bengtsson, J., J. Ahnström, and A. C. Weibull. 2005. The effects of organic agriculture on biodiversity and abundance: a meta-analysis. Journal of Applied Ecology 42(2):261-269. http://dx.doi.org/10.1111/j.1365-2664.2005.01005.x

Benton, T. G., J. A. Vickery, and J. S. Wilson. 2003. Farmland biodiversity: is habitat heterogeneity the key? Trends in Ecology \& Evolution 18(4):182-188.

Bezdicek, D. F., and D. Granatstein. 1989. Crop rotation efficiencies and biological diversity in farming systems. American Journal of Alternative Agriculture 4(3-4):111-119. http://dx.doi.org/10.1017/S0889189300002927

Bhagwat, S. A., K. J. Willis, H. J. B. Birks, and R. J. Whittaker. 2008. Agroforestry: a refuge for tropical biodiversity?Trends in Ecology \& Evolution23(5):261-267.

Bianchi, F., C. Booij, and T. Tscharntke. 2006. Sustainable pest regulation in agricultural landscapes: a review on landscape composition, biodiversity and natural pest control. Proceedings of the Royal Society B: Biological Sciences 273 (1595):1715. http://dx.doi.org/10.1098/rspb.2006.3530

Birkhofer, K., T. M. Bezemer, J. Bloem, M. Bonkowski, S. Christensen, D. Dubois, F. Ekelund, A. Fließbach, L. Gunst, K. Hedlund, P. Mäder, J. Mikola, C. Robin, H. Setälä, F. TatinFroux, W. H. Van der Putten, and S. Scheu. 2008. Long-term organic farming fosters below and aboveground biota: implications for soil quality, biological control and productivity. Soil Biology and Biochemistry 40(9):2297-2308. http://dx.doi.org/10.1016/j.soilbio.2008.05.007
Brennan, E. B., and N. S. Boyd. 2012. Winter cover crop seeding rate and variety affects during eight years of organic vegetables: II. Cover crop nitrogen accumulation. Agronomy Journal 104(3):799-806. http://dx.doi.org/10.2134/agronj2011.0331

Carvalheiro, L. G., C. L. Seymour, R. Veldtman, and S. W. Nicolson. 2010. Pollination services decline with distance from natural habitat even in biodiversity-rich areas. Journal of Applied Ecology 47(4):810-820. http://dx.doi.org/10.1111/ j.1365-2664.2010.01829.x

Carvalheiro, L. G., R. Veldtman, A. G. Shenkute, G. B. Tesfay, C. W. W. Pirk, J. S. Donaldson, and S. W. Nicolson. 2011. Natural and within-farmland biodiversity enhances crop productivity. Ecology Letters 14(3):251-259. http://dx.doi. org/10.1111/j.1461-0248.2010.01579.x

Chaplin-Kramer, R., M. E. O'Rourke, E. J. Blitzer, and C. Kremen, C. 2011. A meta-analysis of crop pest and natural enemy response to landscape complexity. Ecology Letters 14 (9):922-932. http://dx.doi.org/10.1111/j.1461-0248.2011.01642. $\underline{x}$

Cincotta, R. P., J. Wisnewski, and R. Engelman. 2000. Human population in the biodiversity hotspots. Nature 404 (6781):990-992.

Connor, D. J. 2008. Organic agriculture cannot feed the world. Field Crops Research 106(2):187-190. http://dx.doi. org/10.1016/j.fcr.2007.11.010

Conyers, M. K., and P. W. Moody. 2009. A conceptual framework for improving the $\mathrm{P}$ efficiency of organic farming without inputs of soluble P fertiliser. Crop \& Pasture Science 60(2):100-104. http://dx.doi.org/10.1071/CP06327

Cordell, D., J. O. Drangert, and S. White. 2009. The story of phosphorus: global food security and food for thought. Global Environmental Change-Human and Policy Dimensions 19 (2):292-305. http://dx.doi.org/10.1016/j.gloenvcha.2008.10.009

Crews, T. E., and M. B. Peoples. 2004. Legume versus fertilizer sources of nitrogen: ecological tradeoffs and human needs. Agriculture Ecosystems \& Environment 102 (3):279-297. http://dx.doi.org/10.1016/j.agee.2003.09.018

Crowder, D. W., T. D. Northfield, M. R. Strand, and M. R. Snyder. 2010. Organic agriculture promotes evenness and natural pest control. Nature 466(7302):109-112. http://dx.doi. org/10.1038/nature09183

Daily, G. C., P. R. Ehrlich, and G. A. Sanchez-Azofeifa, G. A. 2001. Countryside biogeography: use of human-dominated habitats by the avifauna of southern Costa Rica. Ecological Applications 11(1):1-13. http://dx.doi.org/10.1890/1051-0761 (2001)011[0001:CBUOHD]2.0.CO;2

de Ponti, T., B. Rijk, and M. K. van Ittersum. 2012. The crop yield gap between organic and conventional agriculture. 
Agricultural Systems 108:1-9. http://dx.doi.org/10.1016/j. agsy.2011.12.004

de Vallavieille-Pope, C. 2004. Management of disease resistance diversity of cultivars of a species in single fields: controlling epidemics. Comptes Rendus Biologies 327 (7):611-620. http://dx.doi.org/10.1016/j.crvi.2003.11.014

DeFries, R. S., T. Rudel, M. Uriarte, and M. Hansen. 2010. Deforestation driven by urban population growth and agricultural trade in the twenty-first century. Nature Geoscience 3(3):178-181. http://dx.doi.org/10.1038/ngeo756

Diaz, R. J., and R. Rosenberg. 2008. Spreading dead zones and consequences for marine ecosystems. Science 321 (5891):926-929. http://dx.doi.org/10.1126/science.1156401

Dolan, M. S., C. E. Clapp, R. R. Allmaras, J. M. Baker, and J. A. E. Molina. 2006. Soil organic carbon and nitrogen in a Minnesota soil as related to tillage, residue and nitrogen management. Soil \& Tillage Research 89(2):221-231. http:// dx.doi.org/10.1016/j.still.2005.07.015

Drinkwater, L., D. Letourneau, F. Workneh, A. Van Bruggen, and C. Shennan. 1995. Fundamental differences between conventional and organic tomato agroecosystems in California. Ecological Applications 5(4):1098-1112. http:// dx.doi.org/10.2307/2269357

Drinkwater, L., P. Wagoner, and M. Sarrantonio. 1998. Legume-based cropping systems have reduced carbon and nitrogen losses. Nature 396(6708):262-265.

Edmeades, D. C. 2003. The long-term effects of manures and fertilisers on soil productivity and quality: a review. Nutrient Cycling in Agroecosystems 66(2):165-180.

Eilers, E. J., C. Kremen, S. S. Greenleaf, A. K. Garber, and A. M. Klein. 2011. Contribution of pollinator-mediated crops to nutrients in the human food supply. PLOS $\mid O N E$. 6(6):e21363. http://dx.doi.org/10.1371/journal.pone.0021363

Enache, A., and R. Ilnicki. 1990. Weed-control by subterranean clover (Trifolium-Subterraneum) used as a living mulch. Weed Technology 4(3):534-538.

Fargione, J., J. Hill, D. Tilman, S. Polasky, and P. Hawthorne, P. 2008. Land clearing and the biofuel carbon debt. Science 319(5867):1235-1238. http://dx.doi.org/10.1126/science.1152747

Fliessbach, A., H. R. Oberholzer, L. Gunst, and P. Mäder, P. 2007. Soil organic matter and biological soil quality indicators after 21 years of organic and conventional farming. Agriculture, Ecosystems \& Environment 118(1-4):273-284. http://dx.doi.org/10.1016/j.agee.2006.05.022

Foley, J. A., R. DeFries, G. Asner, C. Barford, G. Bonan, S. Carpenter, F. Chapin, M. Coe, G. Daily, H. Gibbs, J. Helkowski, T. Holloway, E. Howard, C. Kucharik, C. Monfreda, J. Patz, I. Prentice, N. Ramankutty, and P. Snyder.
2005. Global consequences of land use. Science 309 (5734):570-574. http://dx.doi.org/10.1126/science.1111772

Foley, J. A., N. Ramankutty, K. A. Brauman, E. S. Cassidy, J. S. Gerber, M. Johnston, N. D. Mueller, C. O'Connell, D. K. Ray, P. C. West, C. Balzer, E. M. Bennett, S. R. Carpenter, J. Hill, C. Monfreda, S. Polasky, J. Rockström, J. Sheehan, S. Siebert, D. Tilman, and D. P. M. Zaks. 2011. Solutions for a cultivated planet. Nature 478:337-342. http://dx.doi. org/10.1038/nature10452

Food and Agricultural Organization (FAO). 2011. The state of food insecurity in the world 2011: how does international price volatility affect domestic economies and food security? United Nations, Rome, Italy.

Francis, C. A. 2004. Advances in the design of resourceefficient cropping systems. Pages 15-32 in A. Shrestha, editor. Cropping systems: trends and advances. Food Products Press, Binghamton, New York, USA. http://dx.doi.org/10.1300/ J144v08n01_02

Franzluebbers, A. J. 2004. Tillage and residue management effects on soil organic matter. Pages 227-268 in F. Magdoff and R. R. Weil, editors. Soil organic matter in sustainable agriculture. CRC Press, Boca Raton, Florida, USA. http://dx. doi.org/10.1201/9780203496374.ch8

Fuller, R., L. Norton, R. Feber, P. Johnson, D. Chamberlain, A. Joys, F. Mathews, R. Stuart, M. Townsend, and W. Manley. 2005. Benefits of organic farming to biodiversity vary among taxa. Biology letters 1(4):431. http://dx.doi.org/10.1098/ rsbl.2005.0357

Gabriel, D., I. Roschewitz, T. Tscharntke, and C. Thies. 2006. Beta diversity at different spatial scales: plant communities in organic and conventional agriculture. Ecological Applications 16(5):2011-2021. http://dx.doi.org/10.1890/1051-0761(2006) 016[2011:BDADSS]2.0.CO;2

Gabriel, D., S. M. Sait, J. A. Hodgson, U. Schmutz, W. E. Kunin, and T. G. Benton. 2010. Scale matters: the impact of organic farming on biodiversity at different spatial scales. Ecology Letters 13(7):858-869. http://dx.doi.org/10.1111/ j.1461-0248.2010.01481.x

Gardiner, M. M., D. A. Landis, C. Gratton, C. D. DiFonzo, M. O'Neal, J. M. Chacon, M. T. Wayo, N. P. Schmidt, E. E. Mueller, and G. E. Heimpel. 2009. Landscape diversity enhances biological control of an introduced crop pest in the north-central USA. Ecological Applications 19(1):143-154.

Gardner, J. B., and L. E. Drinkwater. 2009. The fate of nitrogen in grain cropping systems: a meta-analysis of N-15 field experiments. Ecological Applications 19(8):2167-2184.

Garibaldi, L. A., I. Steffan-Dewenter, C. Kremen, J. M. Morales, R. Bommarco, S. A. Cunningham, L. G. Carvalheiro, N. P. Chacoff, J. Dudenhöffer, S. S. Greenleaf, A. Holzschuh, 
R. Isaacs, K. Krewenka, Y. Mandelik, M. M. Mayfield, L. A. Morandin, S. G. Potts, T. H. Ricketts, H. Szentgyörgyi, B. F. Viana, C. Westphal, R. Winfree, and A. M. Klein. 2011. Stability of pollination services decreases with isolation from natural areas despite honey bee visits. Ecology Letters 14 (10):1062-1072. http://dx.doi.org/10.1111/j.1461-0248.2011.01669. $\underline{\mathrm{X}}$

Geiger, F., J. Bengtsson, F. Berendse, W. W. Weisser, M. Emmerson, M. B. Morales, P. Ceryngier, J. Liira, T. Tscharntke, and C. Winqvist. 2010. Persistent negative effects of pesticides on biodiversity and biological control potential on European farmland. Basic and Applied Ecology 11 (2):97-105. http://dx.doi.org/10.1016/j.baae.2009.12.001

Glover, J. D., C. M. Cox, and J. P. Reganold. 2007. Future farming: a return to roots? Scientific American 297:82-89.

Godfray, H. C. J., J. R. Beddington, I. R. Crute, L. Haddad, D. Lawrence, J. F. Muir, J. Pretty, S. Robinson, S. M. Thomas, S. M., and C. Toulmin. 2010. Food security: the challenge of feeding 9 billion people. Science 327(5967):812-818. http:// dx.doi.org/10.1126/science.1185383

Gomiero, T., D. Pimentel, and M. G. Paoletti. 2011a. Environmental impact of different agricultural management practices: conventional vs. organic agriculture. Critical Reviews in Plant Sciences 30(1):95-124.

Gomiero, T., D. Pimentel, and M G. Paoletti. 2011b. Is there a need for a more sustainable agriculture? Critical Reviews in Plant Sciences 30(1):6-23.

Grandy, A. S., and G. P. Robertson. 2007. Land-use intensity effects on soil organic carbon accumulation rates and mechanisms. Ecosystems 10(1):59-74. http://dx.doi.org/10.1007/ s10021-006-9010-y

Green, R. E., S. J. Cornell, J. P. W. Scharlemann, and A. Balmford. 2005. Farming and the fate of wild nature. Science 307(5709):550-555. http://dx.doi.org/10.1126/science.1106049

Hajjar, R., D. I. Jarvis, and B. Gemmill-Herren, B. 2008. The utility of crop genetic diversity in maintaining ecosystem services. Agriculture Ecosystems \& Environment 123 (4):261-270. http://dx.doi.org/10.1016/j.agee.2007.08.003

Hauggaard-Nielsen, H., and Jensen, E. S. 2005. Facilitative root interactions in intercrops. Plant and Soil 274 (1-2):237-250.

Hayes, T. B., V. Khoury, A. Narayan, M. Nazir, A. Park, T. Brown, L. Adame, E. Chan, D. Buchholz, and T. Stueve. 2010. Atrazine induces complete feminization and chemical castration in male African clawed frogs (Xenopus laevis). Proceedings of the National Academy of Sciences 107 (10):4612. http://dx.doi.org/10.1073/pnas.0909519107
Hazell, P., and S. Wood. 2008. Drivers of change in global agriculture. Philosophical Transactions of the Royal Society B-Biological Sciences 363(1491):495-515. http://dx.doi. org/10.1098/rstb.2007.2166

Hiddink, G. A., A. J. Termorshuizen, and A. H. C. Bruggen. 2010. Mixed cropping and suppression of soilborne diseases. Pages 119-146 in E. Lichtfouse, editor. Genetic Engineering, Biofertilisation, Soil Quality and Organic Farming. Sustainable Agriculture Reviews, Volume 4. Springer Science+Business Media, Dordrecht, The Netherlands. http:// dx.doi.org/10.1007/978-90-481-8741-6 5

Holt-Giménez, E. 2002. Measuring farmers' agroecological resistance after Hurricane Mitch in Nicaragua: a case study in participatory, sustainable land management impact monitoring. Agriculture, Ecosystems \& Environment 93 (1-3):87-105. http://dx.doi.org/10.1016/S0167-8809(02)00006-3

Holzschuh, A., I. Steffan-Dewenter, and T. Tscharntke. 2008. Agricultural landscapes with organic crops support higher pollinator diversity. Oikos 117(3):354-361. http://dx.doi. org/10.1111/j.2007.0030-1299.16303.x

Holzschuh, A., I. Steffan-Dewenter, D. Kleijn, and T. Tscharntke. 2007. Diversity of flower-visiting bees in cereal fields: effects of farming system, landscape composition and regional context. Journal of Applied Ecology 44(1):41-49. http://dx.doi.org/10.1111/j.1365-2664.2006.01259.x

Hooper, D. U., F. S. Chapin, J. J. Ewel, A. Hector, P. Inchausti, S. Lavorel, J. H. Lawton, D. M. Lodge, M. Loreau, S. Naeem, B. Schmid, H. Setälä, A. J. Symstad, J. Vandermeer, and D. A. Wardle. 2005. Effects of biodiversity on ecosystem functioning: a consensus of current knowledge. Ecological Monographs 75(1):3-35. http://dx.doi.org/10.1890/04-0922

Hudson, B. 1994. Soil organic matter and available water capacity. Journal of Soil and Water Conservation 49 (2):189-194.

Iles, A., and R. Marsh. 2012. Nurturing diversified farming systems in industrialized countries: how public policy can contribute. Ecology and Society 17(4): 42. http://dx.doi. org/10.5751/ES-05041-170442

International Assessment of Agricultural Knowledge, Science and Technology for Development (IAASTD). 2009. Global report: agriculture at a crossroads. Island Press, Washington, D.C., USA.

Jackson, L., T. Rosenstock, M. Thomas, J. W. Wright, and A. Symstad. 2009. Managed ecosystems: biodiversity and ecosystem functions in landscapes modified by human use. Pages 178-194 in Shahid Naeem, Daniel E. Bunker, Andy Hector, Michel Loreau, Charles Perrings, editor. Biodiversity, 
Ecosystem Functioning, \& Human Wellbeing. Oxford University Press Inc., New York, New York, USA. http://dx. doi.org/10.1093/acprof:oso/9780199547951.003.0013

Khan, Z., C. Midega, J. Pittchar, J. Pickett, J., and T. Bruce. 2011. Pushpull technology: a conservation agriculture approach for integrated management of insect pests, weeds and soil health in Africa. International Journal of Agricultural Sustainability 9(1):162-170.

Khan, Z. R., K. Ampong-Nyarko, P. Chiliswa, A. Hassanali, S. Kimani, W. Lwande, W. Overholt, J. Picketta, L. Smart, and C. Woodcock. 1997. Intercropping increases parasitism of pests. Nature 388(6643):631-632.

Khan, Z. R., and J. A. Pickett. 2004. The 'push-pull' strategy for stemborer management: a case study in exploiting biodiversity and chemical ecology. Pages 155-164 in G. M. Gurr, S. D. Wratten, and M. A. Altieri, editors. Ecological engineering for pest management: advances in habitat manipulation for arthropods. CSIRO Publishing, Collingwood, Victoria, Australia; CABI Publishing, Wallingford, Oxfordshire, UK; and Cornell University Press, Ithaca, New York, USA.

Khan, Z. R., J. A. Pickett, J. Berg, L. J. Wadhams, and C. M. Woodcock, C. M. 2000. Exploiting chemical ecology and species diversity: stem borer and striga control for maize and sorghum in Africa. Pest management science 56(11):957-962. http://dx.doi.org/10.1002/1526-4998(200011)56:11<957::AIDPS236>3.0.CO;2-T

Kirchmann, H., L. Bergstrom, T. Katterer, O. Andren, and R. Andersson. 2008. Can organic crop production feed the world? Pages 39-72 in H. Kirchmann and L. Bergstrom, editors. Organic Crop Production - Ambitions and Limitations. Springer Science+Business Media, .

Kleijn, D., R. A. Baquero, Y. Clough, M. Diaz, J. De Esteban, F. Fernandez, D. Gabriel, F. Herzog, A. Holzschuh, R. Johl, E. Knop, A., Kruess, E. J. P. Marshall, I. Steffan-Dewenter, T. Tscharntke, J. Verhulst, T. M. West, and J. L. Yela. 2006. Mixed biodiversity benefits of agri-environment schemes in five European countries. Ecology Letters 9(3):243-254. http:// dx.doi.org/10.1111/j.1461-0248.2005.00869.x

Klein, A. M., B. Vaissière, J. H. Cane, I. Steffan-Dewenter, S. A. Cunningham, C. Kremen, and T. Tscharntke. 2007. Importance of crop pollinators in changing landscapes for world crops. Proceedings of the Royal Society of London Series B-Biological Sciences 274:303-313. http://dx.doi. org/10.1098/rspb.2006.3721

Knudsen, M. T., H. Hauggaard-Nielsen, B. Jornsgard, and E. S. Jensen, E. S. 2004. Comparison of interspecific competition and $\mathrm{N}$ use in pea-barley, faba bean-barley and lupin-barley intercrops grown at two temperate locations. Journal of
Agricultural Science 142:617-627. http://dx.doi.org/10.1017/ $\underline{\text { S0021859604004745 }}$

Kong, A. Y. Y., J. Six, D. C. Bryant, R. F. Denison, and C. Van Kessel. 2005. The relationship between carbon input, aggregation, and soil organic carbon stabilization in sustainable cropping systems. Soil Science Society of America Journal 69(4):1078-1085. http://dx.doi.org/10.2136/sssaj2004.0215

Kravchenko, A. N., and G. P. Robertson. 2011. Whole-profile soil carbon stocks: the danger of assuming too much from Analyses of too little. Soil Science Society of America Journal 75(1):235-240. http://dx.doi.org/10.2136/sssaj2010.0076

Kremen, C., A. Iles, and C. Bacon. 2012. Diversified farming systems: an agroecological, systems-based alternative to modern industrial agriculture. Ecology and Society 17(4): 44. http://dx.doi.org/10.5751/ES-05103-170444

Kremen, C., N. M. Williams, and R. W. Thorp. 2002. Crop pollination from native bees at risk from agricultural intensification. Proceedings of the National Academy of Sciences 99:16812-16816. http://dx.doi.org/10.1073/pnas.262413599

Lal, R. 2004. Soil carbon sequestration impacts on global climate change and food security. Science 304 (5677):1623-1627. http://dx.doi.org/10.1126/science.1097396

Lammerts van Bueren, E. T., S. Jones, L. Tamm, K. Murphy, J. Myers, C, Leifert, and M. Messmer. 2011. The need to breed crop varieties suitable for organic farming, using wheat, tomato and broccoli as examples: a review. NJAS-Wageningen Journal of Life Sciences 58(3):193-205. http://dx.doi. org/10.1016/j.njas.2010.04.001

Letourneau, D. K., I. Armbrecht, B. Salguero Rivera, J. Montoya Lerma, E. Jimenez Carmona, M., Constanza Daza, S. Escobar, V. Galindo, C. Gutierrez, S. Duque Lopez, J. Lopez Mejia, A. M. Acosta Rangel, J. Herrera Rangel, L. Rivera, C. Arturo Saavedra, A. Marina Torres, and A. Reyes Trujillo. 2011. Does plant diversity benefit agroecosystems? A synthetic review. Ecological Applications 21(1):9-21. http:// dx.doi.org/10.1890/09-2026.1

Letourneau, D. K., and S. G. Bothwell. 2008. Comparison of organic and conventional farms: challenging ecologists to make biodiversity functional. Frontiers in Ecology and the Environment 6(8):430-438. http://dx.doi.org/10.1890/070081

Letourneau, D. K., and B. Goldstein. 2001. Pest damage and arthropod community structure in organic vs. conventional tomato production in California. Journal of Applied Ecology 38(3):557-570. http://dx.doi.org/10.1046/j.1365-2664.2001.00611. $\underline{\mathrm{x}}$

Letourneau, D. K., J. A. Jedlicka, S. G. Bothwell, and C. R. Moreno. 2009. Effects of natural enemy biodiversity on the suppression of arthropod herbivores in terrestrial ecosystems. 
Annual Review of Ecology, Evolution, and Systematics 40:573-592. http://dx.doi.org/10.1146/annurev.ecolsys.110308.120320

Li, L., S. Li, J. Sun, L. Zhou, X. Bao, H. Zhang, and F. Zhang, F. 2007. Diversity enhances agricultural productivity via rhizosphere phosphorus facilitation on phosphorus-deficient soils. Proceedings of the National Academy of Sciences of the United States of America 104(27):11192-11196. http://dx.doi. org/10.1073/pnas.0704591104

Liebman, M., and E. Dyck. 1993. Crop rotation and intercropping strategies for weed management. Ecological Applications 3(1):92-122. http://dx.doi.org/10.2307/1941795

Lin, B. B. 2007. Agroforestry management as an adaptive strategy against potential microclimate extremes in coffee agriculture. Agricultural and Forest Meteorology 144 (1-2):85-94. http://dx.doi.org/10.1016/j.agrformet.2006.12.009

Lin, B. B. 2011. Resilience in agriculture through crop diversification: adaptive management for environmental change. Bioscience 61(3):183-193. http://dx.doi.org/10.1525/ bio.2011.61.3.4

Lin, B. B., I. Perfecto, and J. Vandermeer. 2008. Synergies between agricultural intensification and climate change could create surprising vulnerabilities for crops. Bioscience 58 (9):847-854. http://dx.doi.org/10.1641/B580911

Lipson, M. 1997. Searching for the" O-word": analyzing the USDA current research information system for pertinence to organic farming. Organic Farming Research Foundation, Santa Cruz, California, USA.

Liu, B., C. Tu, S. Hu, M. Gumpertz, and J. B. Ristaino. 2007. Effect of organic, sustainable, and conventional management strategies in grower fields on soil physical, chemical, and biological factors and the incidence of Southern blight. Applied Soil Ecology 37(3):202-214. http://dx.doi.org/10.1016/ j.apsoil.2007.06.007

Lotter, D., R. Seidel, and W. Liebhardt. 2003. The performance of organic and conventional cropping systems in an extreme climate year. American Journal of Alternative Agriculture 18(3):146-154. http://dx.doi.org/10.1079/AJAA200345

Lynch, D. H., R. MacRae, and R. C. Martin. 2011. The carbon and global warming potential impacts of organic farming: does it have a significant role in an energy constrained world? Sustainability 3(2):322-362.

Mäder, P., A. Fliessbach, D. Dubois, L. Gunst, P. Fried, and U. Niggli. 2002. Soil fertility and biodiversity in organic farming. Science 296(5573):1694. http://dx.doi.org/10.1126/ science. 1071148

Marks, A. R., K. Harley, A. Bradman, K. Kogut, D. B. Barr, C. Johnson, N. Calderon, and B. Eskenazi, B. 2010. Organophosphate pesticide exposure and attention in young
Mexican-American children: the CHAMACOS study. Environmental Health Perspectives 118(12):1768. http://dx. doi.org/10.1289/ehp.1002056

Marriott, E. E., and M. M. Wander. 2006. Total and labile soil organic matter in organic and conventional farming systems. Soil Science Society of America Journal 70(3):950-959. http:// dx.doi.org/10.2136/sssaj2005.0241

Marshall, E. J. P., V. K. Brown, N. D. Boatman, P. J. W. Lutman, G. R. Squire, and L. K. Ward. 2003. The role of weeds in supporting biological diversity within crop fields. Weed Research 43(2):77-89. http://dx.doi.org/10.1046/ j.1365-3180.2003.00326.x

Mayfield, M. M., and G. C. Daily. 2005. Countryside biogeography of neotropical herbaceous and shrubby plants. Ecological Applications 15(2):423-439. http://dx.doi. org/10.1890/03-5369

Meehan, T. D., B. P. Werling, D. A. Landis, and C. Gratton, C. 2011. Agricultural landscape simplification and insecticide use in the Midwestern United States. Proceedings of the National Academy of Sciences of the United States of America 108(28):11500-11505. http://dx.doi.org/10.1073/pnas.1100751108

Miao, Y. X., B. A. Stewart, and F. S. Zhang. 2011. Long-term experiments for sustainable nutrient management in China: a review. Agronomy for Sustainable Development 31 (2):397-414. http://dx.doi.org/10.1051/agro/2010034

Millennium Ecosystem Assessment. 2005. Ecosystems and human well-being: synthesis. Island Press, Washington, D.C., USA.

Mondelaers, K., J. Aertsens, and G. Van Huylenbroeck. 2009. A meta-analysis of the differences in environmental impacts between organic and conventional farming. British Food Journal 111(10):1098-1119. http://dx.doi.org/10.1108/0007$\underline{0700910992925}$

Morandin, L. A., and M. Winston. 2005. Wild bee abundance and seed production in conventional, organic, and genetically modified canola. Ecological Applications 15(3):871-881. http://dx.doi.org/10.1890/03-5271

Morandin, L. A., and M. L. Winston. 2006. Pollinators provide economic incentive to preserve natural land in agroecosystems. Agriculture Ecosystems \& Environment 116 (3-4):289-292. http://dx.doi.org/10.1016/j.agee.2006.02.012

Morton, D. C., R. S. DeFries, Y. E. Shimabukuro, L. O. Anderson, E. Arai, F. D. Espirito-Santo, R. Freitas, and J. Morisette. 2006. Cropland expansion changes deforestation dynamics in the southern Brazilian Amazon. Proceedings of the National Academy of Sciences of the United States of America 103(39):14637-14641. http://dx.doi.org/10.1073/ pnas.0606377103 
Murphy, K. M., K. G. Campbell, S. R. Lyon, and S. S. Jones. 2007. Evidence of varietal adaptation to organic farming systems. Field Crops Research 102(3):172-177. http://dx.doi. org/10.1016/j.fcr.2007.03.011

Neumann, P., and N. L. Carreck. 2010. Honey bee colony losses. Journal of Apicultural Research 49(1):1-6.

Norris, R., and M. Kogan. 2005. Ecology of interactions between weeds and arthropods. Annual Review of Entomology 50:479-503. http://dx.doi.org/10.1146/annurev.

ento.49.061802.123218

Park, S., P. Croteau, K. Boering, D. Etheridge, D. Ferretti, P. Fraser, K. Kim, P. Krummel, R. Langenfelds, and T. van Ommen. 2012. Trends and seasonal cycles in the isotopic composition of nitrous oxide since 1940. Nature Geoscience 5(4):261-265. http://dx.doi.org/10.1038/ngeo1421

Pearson, C. J. 2007. Regenerative, semiclosed systems: a priority for twenty-first-century agriculture. Bioscience 57 (5):409-418. http://dx.doi.org/10.1641/B570506

Pelletier, N., E. Audsley, S., Brodt, T. Garnett, P. Henriksson, A. Kendall, K. J. Kramer, D. Murphy, T. Nemecek, and M. Troell. 2011. Energy intensity of agriculture and food systems. Annual Review of Environment and Resources 36:223-246. http://dx.doi.org/10.1146/annurev-environ-081710-161014

Perfecto, I., and J. Vandermeer,. 2010. The agroecological matrix as alternative to the land-sparing/agriculture intensification model. Proceedings of the National Academy of Sciences 107(13):5786. http://dx.doi.org/10.1073/pnas.0905455107

Phalan, B., M. Onial, A. Balmford, and R. E. Green. 2011. Reconciling food production and biodiversity conservation: land sharing and land sparing compared. Science 333 (6047):1289-1291. http://dx.doi.org/10.1126/science.1208742

Philpott, S. M., W. J. Arendt, I. Armbrecht, P. Bichier, T. V. Diestch, C. Gordon, R. Greenberg, I. Perfecto, R. ReynosoSantos, and L. Soto-Pinto. 2008a. Biodiversity loss in Latin American coffee landscapes: review of the evidence on ants, birds, and trees. Conservation Biology 22(5):1093-1105.

Philpott, S. M., B. B. Lin, S. Jha, and S. J. Brines. 2008b. A multi-scale assessment of hurricane impacts on agricultural landscapes based on land use and topographic features. Agriculture, Ecosystems \& Environment 128(1-2):12-20.

Pimentel, D. 2009. Environmental and economic costs of the application of pesticides primarily in the United States. Pages 89-111 in R. Peshin, and A. K. Dhawan, editors. Integrated Pest Management: Innovation-Development Process, Volume 1. Springer Science+Business Media, Dordrecht, The Netherlands.

Pimentel, D. 2010. The effects of antibiotic and pesticide resistance on public health. Pages 294-300 in Antibiotic
Resistance: Implications for Global Health and Novel Intervention Strategies-Workshop Summary. Institute of Medicine (US) Forum on Microbial Threats, Washington, D. C., USA; and National Academies Press, Washington, D.C., USA.

Pimentel, D., P. Hepperly, J. Hanson, D. Douds, and R. Seidel. 2005. Environmental, energetic, and economic comparisons of organic and conventional farming systems. Bioscience 55 (7):573-582. http://dx.doi.org/10.1641/0006-3568(2005)055 [0573:EEAECO 2.0.CO;2

Potts, S. G., J. C. Biesmeijer, C. Kremen, P. Neumann, O. Schweiger, and W.E. Kunin. 2010. Global pollinator declines: trends, impacts and drivers. Trends in Ecology \& Evolution 25(6):345-353. http://dx.doi.org/10.1016/j.tree.2010.01.007

Potts, S. G., B. A. Woodcock, S. P. M. Roberts, T. Tscheulin, E. S. Pilgrim, V. K. Brown, and J. R. Tallowin. 2009. Enhancing pollinator biodiversity in intensive grasslands. Journal of Applied Ecology 46(2):369-379. http://dx.doi. org/10.1111/j.1365-2664.2009.01609.x

Pretty, J., A. Noble, D. Bossio, J. Dixon, R. Hine, F. W. T. P. De Vries, and J. Morison. 2006. Resource-conserving agriculture increases yields in developing countries. Environmental Science \& Technology 40(4):1114-1119. http://dx.doi.org/10.1021/es051670d

Raudsepp-Hearne, C., G. D. Peterson, M. Tengo, E. M., Bennett, T. Holland, K. Benessaiah, G. K. MacDonald, and L. Pfeifer. 2010. Untangling the environmentalist's paradox: why is human well-being increasing as ecosystem services degrade? Bioscience 60(8):576-589.

Reganold, J. P., P. K. Andrews, J. R. Reeve, L. CarpenterBoggs, C. W. Schadt, J. R. Alldredge, C. F. Ross, N. M. Davies, J. Zhou, and H. El-Shemy. A. 2010. Fruit and soil quality of organic and conventional strawberry agroecosystems.PLOS | ONE 5(9):e12346. http://dx.doi.org/10.1371/journal.pone.0012346

Reganold, J. P., L. F. Elliott, and Y. L. Unger. 1987. Longterm effects of organic and conventional farming on soil erosion. Nature 330(6146):370-372. http://dx.doi. org/10.1038/330370a0

Ricketts, T. H., J. Regetz, I. Steffan-Dewenter, S. A. Cunningham, C. Kremen, A. Bogdanski, B. Gemmill-Herren, S. S. Greenleaf, A. M. Klein, M. M. Mayfield, L. A. Morandin, A. Ochieng, and B. F. Viana. 2008. Landscape effects on crop pollination services: are there general patterns? Ecology Letters 11(5):499-515.

Rosenthal, R,. and M. R. DiMatteo. 2001. Meta-analysis: recent developments in quantitative methods for literature reviews. Annual Review of Psychology 52:59-82. http://dx. doi.org/10.1146/annurev.psych.52.1.59 
Rosset, P. M. 1999. The multiple functions and benefits of small farm agriculture. Food First: The Institute for Food and Development Policy, Oakland, California, USA. http://dx.doi. org/10.1057/palgrave.development.1110149

Rosset, P. M., B. M. Sosa, A. M. R. Jaime, and D. R. A. Lozano. 2011. The campesino-to-campesino agroecology movement of ANAP in Cuba: social process methodology in the construction of sustainable peasant agriculture and food sovereignty. Journal of Peasant Studies 38(1):161-191.

Rudel, T. K. 2007. Changing agents of deforestation: from state-initiated to enterprise driven processes, 1970-2000. Land Use Policy 24(1):35-41. http://dx.doi.org/10.1016/j. landusepol.2005.11.004

Rudel, T. K., L. Schneider, M. Uriarte, B. L. Turner, R. DeFries, D. Lawrence, J. Geoghegan, S. Hecht, A. Ickowitz, E. F. Lambin, T. Birkenholtz, S. Baptista, and R. Grau. 2009. Agricultural intensification and changes in cultivated areas, 1970-2005. Proceedings of the National Academy of Sciences of the United States of America 106(49):20675-20680. http:// dx.doi.org/10.1073/pnas.0812540106

Scales, B. R., and S. Marsden, S. J. 2008. Biodiversity in smallscale tropical agroforests: a review of species richness and abundance shifts and the factors influencing them. Environmental Conservation 35(02):160-172. http://dx.doi. org/10.1017/S0376892908004840

Seufert, V., N. Ramankutty, and J. A. Foley. 2012. Comparing the yields of organic and conventional agriculture. Nature 485(7397):229-U113. http://dx.doi.org/10.1038/nature11069

Shelton, A., and F. Badenes-Perez. 2006. Concepts and applications of trap cropping in pest management. Annual Review of Entomology 51:285-308. http://dx.doi.org/10.1146/ annurev.ento.51.110104.150959

Shennan, C. 2008. Biotic interactions, ecological knowledge and agriculture. Philosophical Transactions of the Royal Society B-Biological Sciences 363(1492):717-739. http://dx. doi.org/10.1098/rstb.2007.2180

Shennan, C., J. Muramoto, S. T. Koike, O. Daugovish, C. Matthews, G. Tanimura, and T. Flewell. 2009. Optimizing anaerobic soil disinfestation for non-fumigated strawberry production in California. Proceedings of the Annual International Research Conference on Methyl Bromide Alternatives and Emissions Reductions 101:1-3.

Snapp, S. S., P. L. Mafongoya, and S. Waddington. 1998. Organic matter technologies for integrated nutrient management in smallholder cropping systems of southern Africa. Agriculture Ecosystems \& Environment 71 (1-3):185-200. http://dx.doi.org/10.1016/S0167-8809(98)00140-6
Sooby, J. 2001. State of the states: organic farming systems research at land grant institutions 2000-2001. Organic Farming Research Foundation, Santa Cruz, California, USA.

Sosnoskie, L. M., C. P. Herms, and J. Cardina. 2006. Weed seedbank community composition in a 35-yr-old tillage and rotation experiment. Weed Science 54(2):263-273.

Stone, A., S. Scheuerell, H. Darby, F. Magdoff, and R. Ray. 2004. Suppression of soilborne diseases in field agricultural systems: organic matter management, cover cropping, and other cultural practices. Pages 131-177 in F. Magdoff and R. R. Weil , editors. Soil organic matter in sustainable agriculture. CRC Press, Boca Raton, Florida, USA.

Syswerda, S. P., A. T. Corbin, D. L. Mokma, A. N. Kravchenko, and G. P. Robertson. 2011. Agricultural management and soil carbon storage in surface vs. deep layers. Soil Science Society of America Journal 75(1):92-101. http:// dx.doi.org/10.2136/sssaj2009.0414

Tamm, L., B. Thurig, A. Fliessbach, A. Goltlieb, S. Karavani, and Y. Cohen. 2011. Elicitors and soil management to induce resistance against fungal plant diseases. NJAS-Wageningen Journal of Life Sciences 58(3-4):131-137. http://dx.doi. org/10.1016/j.njas.2011.01.001

Tengo, M. and K. Belfrage. 2004. Local management practices for dealing with change and uncertainty: a cross-scale comparison of cases in Sweden and Tanzania. Ecology and Society 9(3):4. [online] URL: http://www.ecologyandsociety. org/vol9/iss3/art4/.

Thies, C., I. Roschewitz, and T. Tscharntke. 2005. The landscape context of cereal aphid-parasitoid interactions. Proceedings of the Royal Society B: Biological Sciences 272 (1559):203. http://dx.doi.org/10.1098/rspb.2004.2902

Thies, C., and T. Tscharntke. 1999. Landscape structure and biological control in agroecosystems. Science 285(5429):893. http://dx.doi.org/10.1126/science.285.5429.893

Tilman, D., K. G. Cassman, P. A. Matson, R. Naylor, and S. Polasky. 2002. Agricultural sustainability and intensive production practices. Nature 418(6898):671-677. http://dx. doi.org/10.1038/nature01014

Tomich, T. P., S. Brodt, H. Ferris, R. Galt, W. R. Horwath, E. Kebreab, J. H. J. Leveau, D. Liptzin, M. Lubell, P. Merel, R. Michelmore, T. Rosenstock, K. Scow, J. Six, N., Williams, and L. Yang, L. 2011. Agroecology: a review from a globalchange perspective. Annual Review of Environment and Resources 36:193-222. http://dx.doi.org/10.1146/annurevenviron-012110-121302

Tonhasca Jr, A., and D. N. Byrne. 1994. The effects of crop diversification on herbivorous insects: a meta-analysis approach. Ecological Entomology 19(3):239-244. http://dx. doi.org/10.1111/j.1365-2311.1994.tb00415.x 
Townsend, A. R., R. W. Howarth, F. A. Bazzaz, M. S. Booth, C. C. Cleveland, S. K. Collinge, A. P. Dobson, P. R. Epstein, E. A. Holland, and D. R. Keeney. 2003. Human health effects of a changing global nitrogen cycle. Frontiers in Ecology and the Environment 1(5):240-246.

Tscharntke, T., A. M. Klein, A. Kruess, I. Steffan-Dewenter, and C. Thies. 2005. Landscape perspectives on agricultural intensification and biodiversity-ecosystem service management. Ecology Letters 8(8):857-874. http://dx.doi.org/10.1111/ j.1461-0248.2005.00782.x

Vallad, G. E., and R. M. Goodman. 2004. Systemic acquired resistance and induced systemic resistance in conventional agriculture. Crop Science 44(6):1920-1934. http://dx.doi. org/10.2135/cropsci2004.1920

Vandermeer, J., I. Perfecto, and S. Philpott. 2010. Ecological complexity and pest control in organic coffee production: uncovering an autonomous ecosystem service. Bioscience 60 (7):527-537. http://dx.doi.org/10.1525/bio.2010.60.7.8

Vandermeer, J. H. 1992. The ecology of intercropping. Cambridge University Press, Cambridge UK. http://dx.doi. org/10.1017/CBO9780511623523

Vanloqueren, G., and P. V. Baret. 2009. How agricultural research systems shape a technological regime that develops genetic engineering but locks out agroecological innovations. Research Policy 38(6):971-983. http://dx.doi.org/10.1016/j. respol.2009.02.008

Verbruggen, E., W. F. M. Roling, H. A. Gamper, G. A. Kowalchuk, H. A. Verhoef, and M. G. A. van der Heijden. 2010. Positive effects of organic farming on below-ground mutualists: large-scale comparison of mycorrhizal fungal communities in agricultural soils. New Phytologist 186 (4):968-979. http://dx.doi.org/10.1111/j.1469-8137.2010.03230. $\underline{\mathrm{X}}$

Villarejo, D. 2003. The health of US hired farm workers. Annual Review of Public Health 24(1):175-193.

Weil, R. R., and F. Magdoff. 2004. Significance of soil organic matter to soil quality and health. Pages 1-42 in F. Magdoff and R. R. Weil, editors. Soil organic matter in sustainable agriculture. CRC Press, Boca Raton, Florida, USA. http://dx. doi.org/10.1201/9780203496374.ch1

Wilcove, D. S., and L. P. Koh. 2010. Addressing the threats to biodiversity from oil-palm agriculture. Biodiversity and Conservation 19(4):999-1007. http://dx.doi.org/10.1007/ s10531-009-9760-X

Winfree, R., R. Aguilar, D. P. Vazquez, G. LeBuhn, and M. A. Aizen. 2009. A meta-analysis of bees' responses to anthropogenic disturbance. Ecology 90(8):2068-2076. http:// dx.doi.org/10.1890/08-1245.1
Winqvist, C., J. Bengtsson, T. Aavik, F. Berendse, L. W. Clement, S. Eggers, C. Fischer, A. Flohre, F. Geiger, and J. Liira. 2011. Mixed effects of organic farming and landscape complexity on farmland biodiversity and biological control potential across Europe. Journal of Applied Ecology 48 (3):570-579. http://dx.doi.org/10.1111/j.1365-2664.2010.01950. $\underline{\mathrm{X}}$

Zewde, T., C. Fininsa, P. K. Sakhuja, and S. Ahmed. 2007. Association of white rot (Sclerotium cepivorum) of garlic with environmental factors and cultural practices in the North Shewa highlands of Ethiopia. Crop Protection 26 (10):1566-1573. http://dx.doi.org/10.1016/j.cropro.2007.01.007

Zhang, F. S., and L. Li. 2003. Using competitive and facilitative interactions in intercropping systems enhances crop productivity and nutrient-use efficiency. Plant and Soil 248(1-2):305-312.

Zhang, W., T. H. Ricketts, C. Kremen, K. Carney, and S. M. Swinton. 2007. Ecosystem services and dis-services to agriculture. Ecological Economics 64:253-260. http://dx.doi. org/10.1016/j.ecolecon.2007.02.024

Zhang, X., X. Liu, M. Zhang, R. A. Dahlgren, and M. Eitzel. 2010. A review of vegetated buffers and a meta-analysis of their mitigation efficacy in reducing nonpoint source pollution. Journal of environmental quality 39(1):76-84. http://dx.doi.org/10.2134/jeq2008.0496

Zhu, Y., H. Chen, J. Fan, Y. Wang, Y. Li, J. Chen, J. X. Fan, S., Yang, L. Hu, and H. Leung. 2000. Genetic diversity and disease control in rice. Nature 406(6797):718-7 